\title{
Seamounts off the West Antarctic margin: A case for non-hotspot driven intraplate volcanism
}

\author{
A. Kipf ${ }^{\text {a,* }}$, F. Hauff a, R. Werner ${ }^{\text {a }}$, K. Gohl ${ }^{\text {b }}$, P. van den Bogaard ${ }^{\text {a }}$, K. Hoernle ${ }^{\text {a }}$, D. Maicher ${ }^{\text {a }}$, A. Klügel ${ }^{\text {c }}$ \\ a GEOMAR Helmholtz Centre for Ocean Research Kiel, Wischhofstr. 1-3, D-24148 Kiel, Germany \\ ${ }^{b}$ Alfred-Wegener-Institute for Polar and Marine Research, Postfach 120161, D-27515 Bremerhaven, Germany \\ c University of Bremen, Postfach 330440, D-28334 Bremen, Germany
}

\section{A R T I C L E I N F O}

\section{Article history:}

Received 21 December 2012

Received in revised form 28 May 2013

Accepted 11 June 2013

Available online 16 July 2013

Handling Editor: I. Safonova

\section{Keywords:}

Antarctica

Marie Byrd Seamounts

Intraplate volcanism

${ }^{40} \mathrm{Ar} /{ }^{39} \mathrm{Ar}$ age dates

Major and trace element and $\mathrm{Sr}-\mathrm{Nd}-\mathrm{Pb}-\mathrm{Hf}$

Isotope geochemistry

\begin{abstract}
A B S T R A C T
New radiometric age and geochemical data of volcanic rocks from the guyot-type Marie Byrd Seamounts (MBS) and the De Gerlache Seamounts and Peter I Island (Amundsen Sea) are presented. ${ }^{40} \mathrm{Ar} /{ }^{39} \mathrm{Ar}$ ages of the shield phase of three MBS are Early Cenozoic (65 to $56 \mathrm{Ma}$ ) and indicate formation well after creation of the Pacific-Antarctic Ridge. A Pliocene age (3.0 Ma) documents a younger phase of volcanism at one MBS and a Pleistocene age (1.8 Ma) for the submarine base of Peter I Island. Together with published data, the new age data imply that Cenozoic intraplate magmatism occurred at distinct time intervals in spatially confined areas of the Amundsen Sea, excluding an origin through a fixed mantle plume. Peter I Island appears strongly influenced by an EMII type mantle component that may reflect shallow mantle recycling of a continental raft during the final breakup of Gondwana. By contrast the $\mathrm{Sr}-\mathrm{Nd}-\mathrm{Pb}-\mathrm{Hf}$ isotopic compositions of the MBS display a strong affinity to a HIMU-type mantle source. On a regional scale the isotopic signatures overlap with those from volcanics related to the West Antarctic Rift System, and Cretaceous intraplate volcanics in and off New Zealand. We propose reactivation of the HIMU material, initially accreted to the base of continental lithosphere during the pre-rifting stage of Marie Byrd Land/Zealandia to explain intraplate volcanism in the Amundsen Sea in the absence of a long-lived hotspot. We propose continental insulation flow as the most plausible mechanism to transfer the sub-continental accreted plume material into the shallow oceanic mantle. Crustal extension at the southern boundary of the Bellingshausen Plate from about 74 to 62 Ma may have triggered adiabatic rise of the HIMU material from the base of Marie Byrd Land to form the MBS. The De Gerlache Seamounts are most likely related to a preserved zone of lithospheric weakness underneath the De Gerlache Gravity Anomaly.
\end{abstract}

(c) 2013 International Association for Gondwana Research. Published by Elsevier B.V. All rights reserved.

\section{Introduction}

Seamounts are common bathymetric features on the seafloor and most are of volcanic origin. Although only a fraction of them have been mapped by ship-based echo-sounding, satellite altimetry has identified more than 13,000 seamounts taller than $1.5 \mathrm{~km}$ and predicts more than 100,000 seamounts higher than $1 \mathrm{~km}$ (e.g., Smith and Sandwell, 1997; Wessel et al., 2010). Seamounts are important probes of the composition and dynamics of the oceanic mantle and, if they form parts of hotspot tracks, they can also be important recorders of past plate motions (Hofmann, 2003; Tarduno et al., 2003; Koppers et al., 2012). They also form oases for marine life and biodiversity (e.g., Shank, 2010 for a recent review) and are significant components of hydrogeological systems focusing the exchange of heat and fluids between the oceanic lithosphere and the oceans (e.g., Fisher et al., 2003; Harris et al., 2004; Hutnak et al., 2008; Klügel et al., 2011). The latter processes can lead to the formation of economically important

\footnotetext{
* Corresponding author. Tel.: +49 4316002645 .

E-mail address: akipf@geomar.de (A. Kipf).
}

mineral deposits (e.g., Hein et al., 2010), which are, for example, commercially mined in some accreted seamount complexes (e.g., Safonova, 2009). Seamounts are also sites of geological hazards such as tsunamis through sector collapse during their growth stage (e.g., McMurtry et al., 2004). Upon subduction of the ocean floor, seamounts can also serve as prominent asperities generating earthquakes (e.g., Watts et al., 2010 for a recent review). As the subduction process can lead to crustal accretion of seamounts, they can be preserved in the accessible geological record, providing important insights from the evolution of hotspot tracks and continental margins to biological exchange between continents (e.g., Hoernle et al., 2002; Geldmacher et al., 2008; Portnyagin et al., 2008; Buchs et al., 2011; Safonova and Santosh, 2012). Despite the manifold contributions of seamounts to the dynamics of diverse earth systems, their process of formation is still debated. Most commonly the occurrence of isolated volcanoes distant from plate boundaries is attributed to the upwelling of mantle plumes (e.g., Wilson, 1963; Morgan, 1971; Courtillot et al., 2003). The absence of linear volcanic chains and lack of spatially age progressive magmatism in many areas has stimulated a vigorous debate on the origin of intraplate volcanism (e.g., Anderson, 2000; Foulger and Natland, 2003; see also "Great 
Plume debate", www.mantleplumes.org). Other important mechanisms of seamount formation include off-axis volcanism in the vicinity of spreading ridges by lateral expansion of the ridge melting regime (e.g., Batiza et al., 1990; Brandl et al., 2012 and references therein), recycling of delaminated continental lithosphere (Hoernle et al., 2011) and plate fracturing (e.g., Winterer and Sandwell, 1987; Natland and Winterer, 2005). In this paper, we report for the first time an integrated bathymetric, geochronological and geochemical data set from three seamount provinces off West Antarctica and show that these intraplate volcanoes are not directly linked to the activity of a mantle plume but rather reflect remobilization and transfer of fertile mantle from beneath West Antarctica.

The Marie Byrd Seamounts (MBS), located in the western Amundsen Sea north of the continental shelf of Marie Byrd Land, West Antarctica (Fig. 1), are a good example of enigmatic intraplate volcanism. They are located on oceanic crust possibly older than 72 Ma (Heinemann et al., 1999; Eagles et al., 2004a,b) and form an elongated cluster of volcanic edifices, that extends for more than $800 \mathrm{~km}$ between $\sim 114^{\circ}$ and $\sim 131^{\circ} \mathrm{W}$, and $\sim 68^{\circ}$ and $\sim 71^{\circ} \mathrm{S}$. Based on rock fragments found in corers and dredges carried out at a single MBS (Hubert Miller Seamount), Udintsev et al. (2007) assumed that this structure represents a relict fragment of continental crust which was destructed and altered by a mantle plume. The authors, however, admit that the material recovered cannot unambiguously be interpreted as in situ rocks. Although the MBS form a vast seamount province covering over $200,000 \mathrm{~km}^{2}$, their remote location made sampling difficult, inhibiting elucidation of their age, magma sources and volcanic evolution. Moreover, the relationship of the MBS to the magmatism associated with the final break-up of Gondwana and/or to the widespread but low volume intraplate volcanism in the SW Pacific region (e.g., Weaver et al., 1994; Storey et al., 1999; Rocchi et al., 2002a; Finn et al., 2005; Hoernle et al., 2006, 2010; Timm et al., 2010) was poorly constrained.

In 2006, the R/V Polarstern cruise ANT-XXIII/4 conducted a bathymetric mapping and dredge sampling survey of five MBS and associated structures. Samples from two other volcanic complexes in the Amundsen Sea, namely the previously studied ocean island volcano Peter I Island (e.g., Prestvik et al., 1990; Prestvik and Duncan, 1991;
Hart et al., 1995) and the Belgica Seamount (De Gerlache Seamounts, Hagedorn et al., 2007) (Fig. 1), are included in our study to more fully characterize the sources and spatial evolution of intraplate magmatism in this region. Both Peter I Island and the De Gerlache Seamounts have been related to hotspot activity by most previous authors.

Here, we present results of the bathymetric surveys together with ${ }^{40} \mathrm{Ar} /{ }^{39} \mathrm{Ar}$ ages and geochemical data (major and trace element and radiogenic $\mathrm{Sr}-\mathrm{Nd}-\mathrm{Pb}-\mathrm{Hf}$ isotope ratios) of the recovered rocks. We show that magmatism in the Amundsen Sea occurred at distinct time intervals in spatially confined areas ruling out an origin through a single stationary hotspot. Notably this volcanism appears predominantly influenced by HIMU (high time-integrated ${ }^{238} \mathrm{U} /{ }^{204} \mathrm{~Pb}$ ) type mantle, requiring emplacement and upwelling of such material in the depleted upper oceanic mantle well after the breakup of Zealandia from Antarctica. After briefly summarizing the tectonic and magmatic evolution affecting this part of the SW Pacific over the past $100 \mathrm{Ma}$, we discuss our results and evaluate processes, which may cause non-hotspot related HIMU-type intraplate volcanism in the Amundsen Sea.

\section{Tectonic and magmatic evolution of the SW-Pacific over the past $100 \mathrm{Ma}$}

Plate-kinematic reconstructions (Fig. 2) demonstrate that Marie Byrd Land was attached to the southeastern margin of Zealandia prior to the final breakup of Gondwana (Fig. 2a; e.g., Eagles et al., 2004a). After the collision of the Hikurangi Plateau with the Gondwana margin (e.g., Davy et al., 2008; Hoernle et al., 2010) and cessation of subduction along the northern margin of Zealandia at c. $100 \mathrm{Ma}$ (e.g., Weaver et al., 1994), extensional processes set in, causing Zealandia to rift from Marie Byrd Land (e.g., Larter et al., 2002; Eagles et al., 2004a; Boger, 2011 for a recent review). The continental breakup initiated with the Chatham Rise separating from the Amundsen Sea Embayment sector during the Cretaceous Normal Polarity Superchron (CNS) at about $90 \mathrm{Ma}$ (Fig. 2b). Thereafter the southwestward rift propagation jumped farther south and separated the Campbell Plateau from Marie Byrd Land just before chron C33 (83-79 Ma), leaving a rifted West Antarctic continental

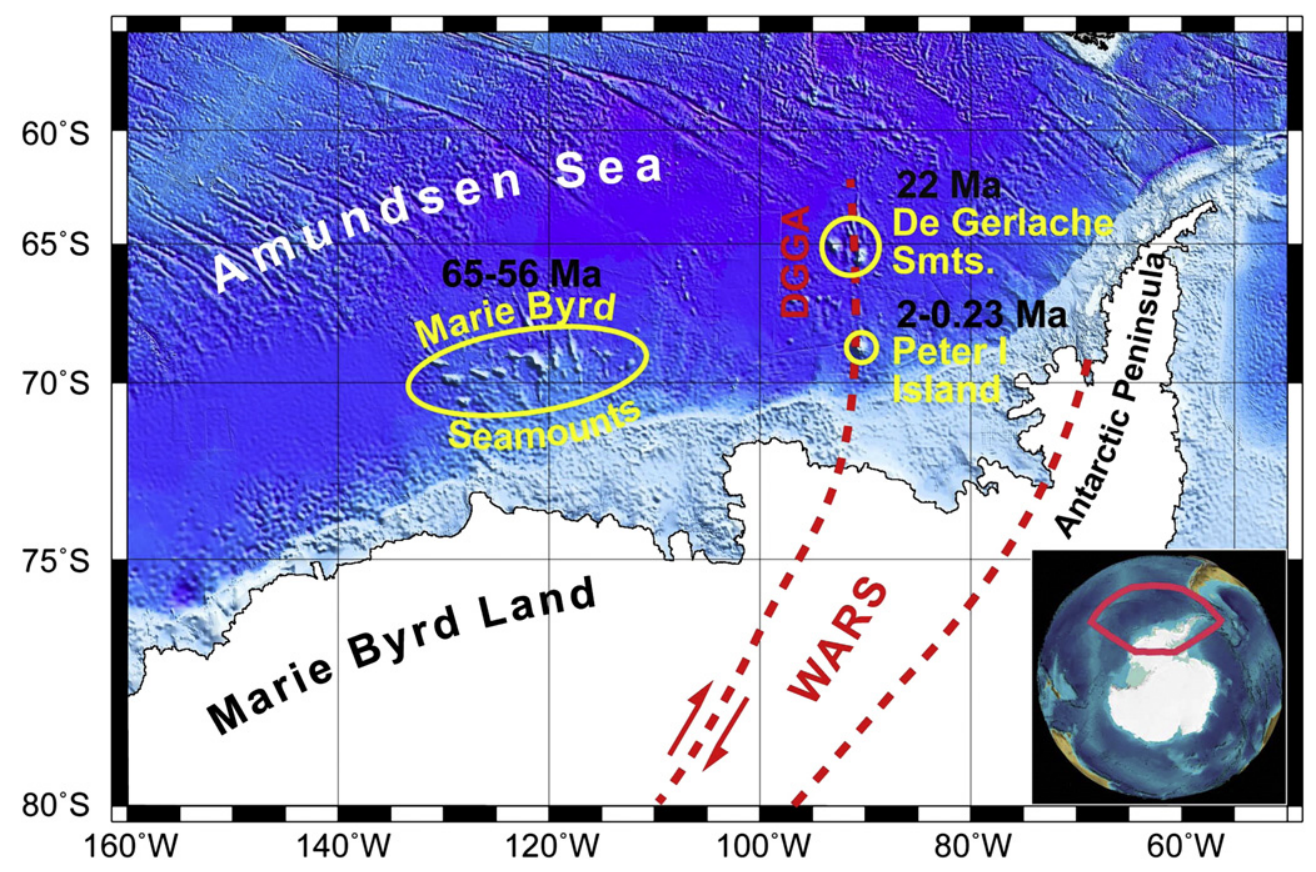

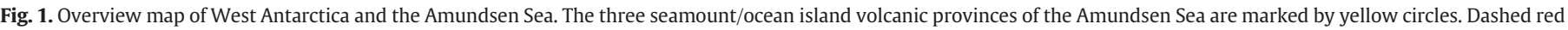

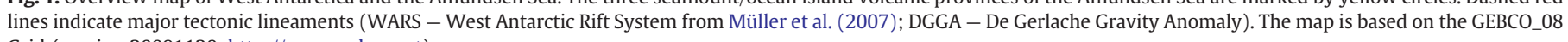
Grid (version 20091120, http://www.gebco.net). 


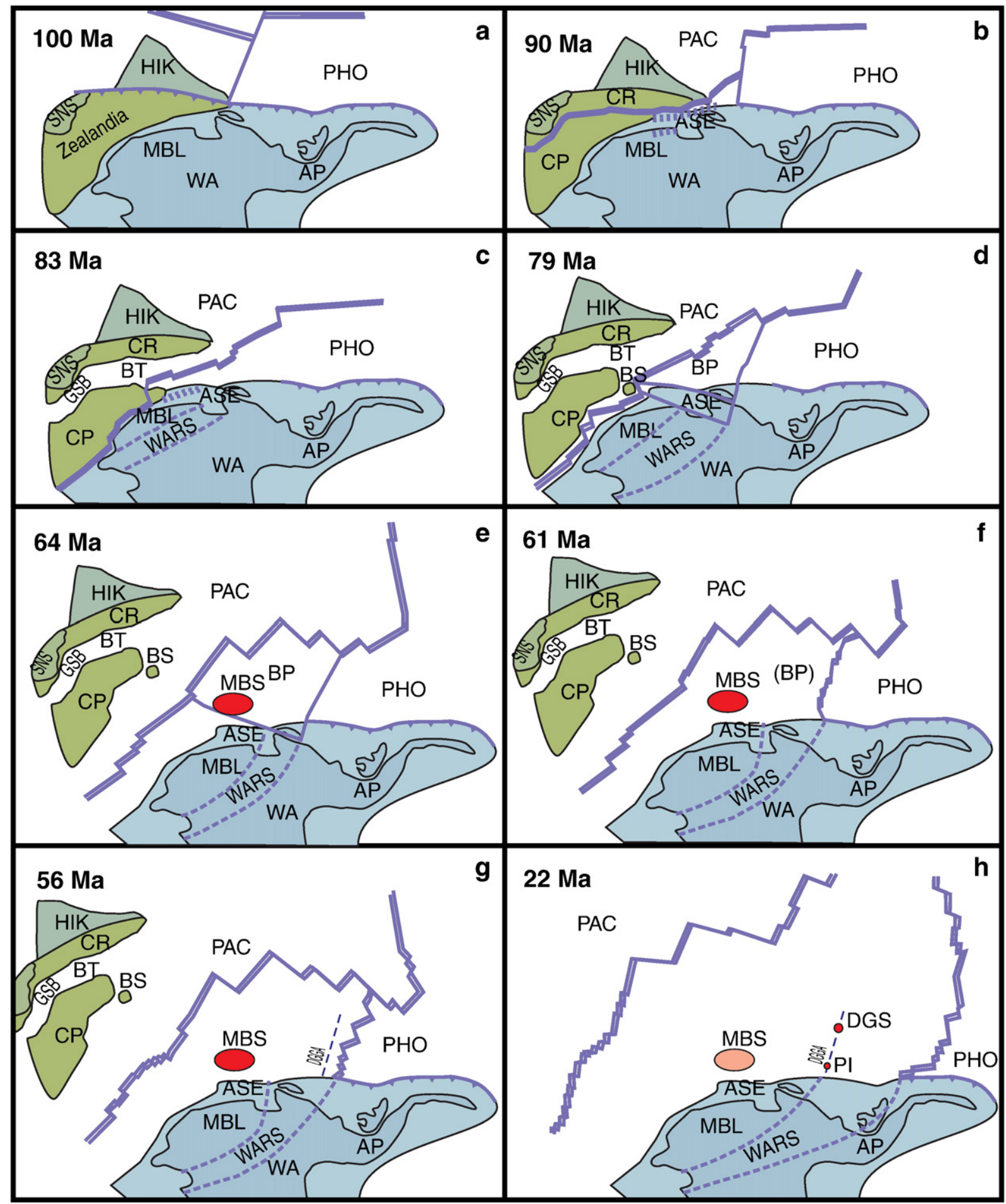

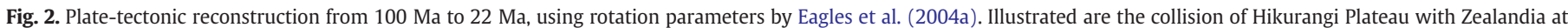

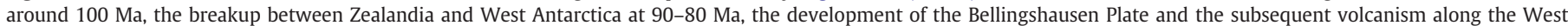

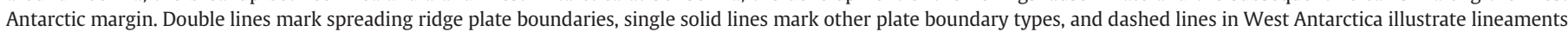

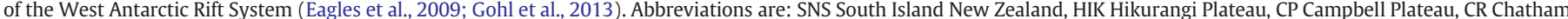

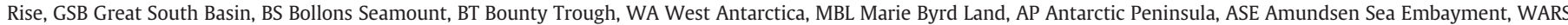

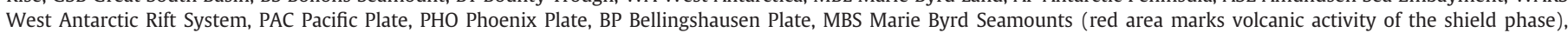
DGS De Gerlache Seamounts, PI Peter I Island, DGGA De Gerlache Gravity Anomaly (suture of former PHO-BP ridge jump).

margin bordering the Amundsen Sea (Fig. 2c, d; Larter et al., 2002; Eagles et al., 2004a).

During the late Cretaceous/Early Tertiary the southern Pacific region was sectioned into a minimum of three major tectonic plates (Bradshaw, 1989; Larter et al., 2002; Eagles et al., 2004a; Wobbe et al.,
2012), the Pacific Plate, the Bellingshausen Plate, and the Phoenix or Aluk Plate adjacent to the Antarctic Plate (Fig. 2e). While the Phoenix Plate subducted beneath the eastern portion of the Antarctic Plate, the other plate boundaries were divergent or transform margins. During C27 (61 Ma) the Bellingshausen Plate ceased from being a separate 
plate and became incorporated into the Antarctic Plate (Fig. 2f; Eagles et al., 2004a,b; Wobbe et al., 2012). Heinemann et al. (1999) and Stock (1997) suggest that the MBS province formed in the vicinity of the Antarctic-Pacific-Bellingshausen triple junction. Between C27 and C25/ C24 (57-54 Ma), a substantial drop in spreading rate occurred at the Pacific-Antarctic Ridge, and together with a gradual rotation of the spreading direction (Müller et al., 2000), an increase in fracture zone density is notable (Eagles et al., 2004a). At the same time, the West Antarctic Rift System (WARS) continued its crustal extension in Marie Byrd Land and possibly into the Amundsen Sea Embayment just south of the MBS (Gohl et al., 2013). The De Gerlache Seamounts and Peter I Island are aligned along the so-called De Gerlache Gravity Anomaly (DGGA) (Gohl et al., 1997a; McAdoo and Laxon, 1997; Hagedorn et al., 2007) (Fig. $2 \mathrm{~g}+\mathrm{h}$ ) which was initially interpreted as a fracture zone of the earlier Phoenix-Antarctic Ridge (Hart et al., 1995). However, magnetic seafloor spreading data imply that this is a tectonic scar caused by a westward jump of the Pacific-Phoenix ridge at chron C27 (Larter et al., 2002; Eagles et al., 2004a). Müller et al. (2007) suggested that this zone of possible lithospheric weakness was reactivated by a northward extension of a later WARS branch (Figs. 1 and $2 \mathrm{~h}$ ).

The Late Cretaceous tectonic events were accompanied by intense volcanism in East Gondwana and Marie Byrd Land at c. 95-110 Ma (e.g., Hart et al., 1997; Storey et al., 1999). This magmatism has been related to large-scale mantle upwelling in conjunction with extensioninduced rifting (Finn et al., 2005). Others assume an active mantle plume in the area of the Bellingshausen-Amundsen Sea or beneath East Gondwana (Hole and LeMasurier, 1994; Weaver et al., 1994; Rocholl et al., 1995; Hart et al., 1995, 1997; Panter et al., 2000; Hoernle et al., 2010; Sutherland et al., 2010), which may have caused the final break-up of Zealandia from Antarctica (e.g., Weaver et al., 1994; Storey et al., 1999; Hoernle et al., 2010). As the region underwent further plate reorganization, a second phase of volcanism occurred (Rocchi et al., 2002a,b; Nardini et al., 2009 and references therein, LeMasurier et al., 1990). This younger magmatism (30-25 Ma until recent) is mainly of alkaline nature and has been related to rifting and crustal extension associated with the WARS. Based on a HIMU (high time-integrated $\mathrm{U} / \mathrm{Pb}$ ) component found in many WARS volcanics, many authors suggest reactivation of old plume material embedded at the base of the continental lithosphere (e.g., Weaver et al., 1994) others favor a metasomatic origin (e.g., Nardini et al., 2009).

\section{Bathymetry and morphology of Marie Byrd Seamounts and Peter I Island}

During cruise ANT-XXIII/4, the onboard Atlas Hydrosweep DS-2 multi-beam echo-sounding system of the R/V Polarstern was used to generate maps of five MBS (summarized in Table 1; Fig. 3a) and of the submarine base of Peter I Island (Gohl, 2007). Combined with bathymetric data of previous cruises (RV Nathaniel B. Palmer in 1996, RV Polarstern ANT-XI/3 in 1994, and ANT-XVIII/5a in 2001; e.g., Miller and Grobe, 1996; Feldberg, 1997), these data reveal that the MBS are characterized by steep sides with relatively flat tops and additional small cones on the upper flanks and/or on the platforms. The guyot-like morphology of the main edifices is attributed to seamount growth above sea level to form ocean island volcanoes, which subsequently eroded to sea level and then subsided to their present position. The small cones must have formed after subsidence of the erosional platforms below wave base and therefore represent a late stage or post-erosional phase of volcanism.

The westernmost studied seamount, Seamount 6 (informal name), has an elongate WNW-ESE striking base (Fig. 3b). The steep-sided edifice is topped by a flat plateau, on which several well-preserved small volcanic cones are scattered, rising up to $200 \mathrm{~m}$ above the plateau. Seamount 9 (informal name) is located about $45 \mathrm{~km}$ east of Seamount 6. One track was surveyed across Seamount 9 (not shown in Fig. 3), which revealed an oval shaped guyot and a c. $10 \mathrm{~km}$ long WNW-ESE-trending ridge emanating from its western base. This ridge is composed of several aligned small volcanic cones and interpreted as volcanic rift zone. Haxby Seamount (named by the ANT-XIII/4 cruise participants) (Fig. 3c), which has been mapped previously on RV Nathaniel B. Palmer Cruise in 1996 (Feldberg, 1997), has a slightly curvilinear volcanic rift system with numerous cones on its top emanating from the eastern flank of the guyot and extending $>30 \mathrm{~km}$ to the east. Two less pronounced, c. $12-15 \mathrm{~km}$ long chains of cones and ridges emanating from the western flank may be the western continuation of the volcanic rift. Hubert Miller Seamount (Fig. 3d) is located $\sim 75 \mathrm{~km}$ ESE of Haxby Seamount. This seamount is the largest MBS with frequent small cones and ridges scattered along its flanks but infrequent on the plateau. Several up to $8 \mathrm{~km}$ long volcanic rift zones extend from the base of Hubert Miller Seamount. The easternmost mapped seamount, Seamount C (informal name; Fig. 3e), is the smallest of the studied volcanoes. Its guyot-shaped edifice has a crudely circular base and a plateau of $\sim 7 \mathrm{~km}$ diameter. Volcanic rifts extend from the base in northern and southern directions and NNE-SSW trending, curvilinear graben and ridge structures are adjacent to its eastern flank. The existence of further, most likely sediment covered, volcanic cones and ridge-like basement structures between the main MBS cluster and Marie Byrd Land are predicted from satellite gravity data (Smith and Sandwell, 1997) and observed in seismic data (Gohl et al., 1997b; Uenzelmann-Neben and Gohl, 2012). The original volume of MBS magmatism, however, remains unclear because of incomplete data and the largely unknown initial volume of the eroded islands. Based on the available bathymetric data (multi-beam and satellite gravity), the total volume of all present MBS can roughly be estimated to more than $20,000 \mathrm{~km}^{3}$. The aerial extent of the former Marie Byrd Islands were similar in size to Canary Islands, such as La Palma (compared to Hubert Miller Seamount) or El Hierro (compared to

Table 1

Morphological features of the Marie Byrd Seamounts.

\begin{tabular}{|c|c|c|c|c|c|}
\hline & Seamount 6 & Seamount 9 & Haxby Seamount & Hubert Miller Seamount & Seamount C \\
\hline Coordinates (center) & $69^{\circ} 47^{\prime} \mathrm{S}, 126^{\circ} 17^{\prime} \mathrm{W}$ & $69^{\circ} 40^{\prime} \mathrm{S}, 124^{\circ} 45^{\prime} \mathrm{W}$ & $69^{\circ} 07^{\prime} \mathrm{S}, 123^{\circ} 35^{\prime} \mathrm{W}$ & $69^{\circ} 17^{\prime} \mathrm{S}, 121^{\circ} 20^{\prime} \mathrm{W}$ & $69^{\circ} 12^{\prime} \mathrm{S}, 117^{\circ} 30^{\prime} \mathrm{W}$ \\
\hline Shape & Oval shaped guyot & Oval shaped guyot & Oval shaped guyot & Oval shaped guyot & Crudely circular guyot \\
\hline Secondary features & $\begin{array}{l}\text { Small cones on flanks } \\
\text { and plateau }\end{array}$ & $\begin{array}{l}\text { Small cones on flanks and } \\
\text { plateau; WNW-ESE } \\
\text { trending rift zone }\end{array}$ & $\begin{array}{l}\text { Small cones on flanks and } \\
\text { plateau; WNW-ESE trending } \\
\text { major rift zone, minor W-E } \\
\text { and WSW-ENE rifts }\end{array}$ & $\begin{array}{l}\text { Small cones on flanks and } \\
\text { plateau; several rift zones, } \\
\text { most of them } \sim \mathrm{SW}-\mathrm{NE}\end{array}$ & $\begin{array}{l}\text { Small cones on flanks and } \\
\text { plateau; rift zones mainly } \\
\text { trending from SSW-NNE to } \\
\text { SSE-NNW }\end{array}$ \\
\hline Base level (mbsl) & $3000-2800$ & $3600-3400$ & 4000 & $4000-3600$ & 3500 \\
\hline Diameter at base $(\mathrm{km})$ & $80 \times 20$ & Long axis 25 & 30 & $75 \times 50$ & 17 \\
\hline Water depth of plateau (mbsl) & $1600-1350$ & $1600-1400$ & $1800-1600$ & $1600-1200$ & $2400-2200$ \\
\hline Edifice height (m) & $\sim 1650$ & $\sim 2200$ & $\sim 2400$ & $\sim 2800$ & $\sim 1300$ \\
\hline Volume estimate $\left(\mathrm{km}^{3}\right)$ & $\sim 2000$ & - & $\sim 1600$ & $\sim 8000$ & $\sim 200$ \\
\hline Dredge samples ${ }^{\mathrm{a}}$ & - & - & PS69/317-1 & $\begin{array}{l}\text { PS69/321-1 } \\
\text { PS69/324-1 } \\
\text { PS69/325-1 }\end{array}$ & PS69/327-1 \\
\hline
\end{tabular}

a A detailed description of dredge operations and recovered material is provided in Gohl (2007). 

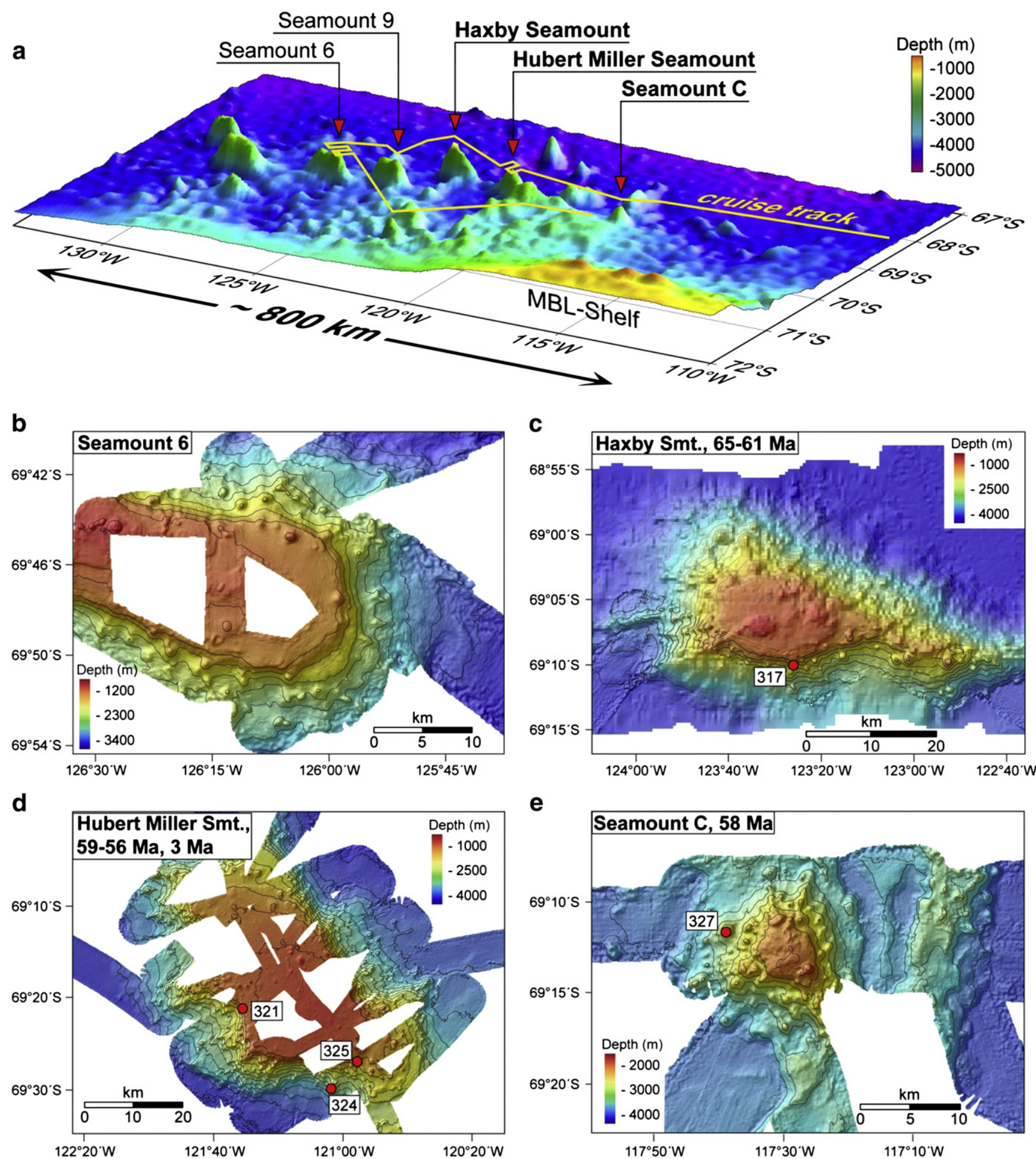

\section{e}

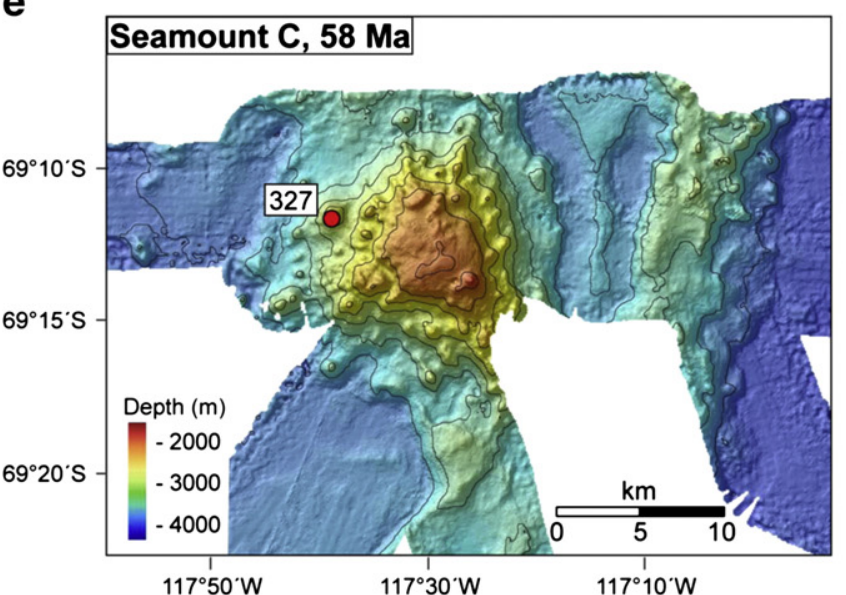

Fig. 3. (a) Overview of the Marie Byrd Seamount Province. Red arrows mark the MBS surveyed during R/V Polarstern cruise ANT-XXIII/4 in 2006, letters in bold signify those which have been successfully dredged. Predicted bathymetry is after Smith and Sandwell (1997). (b) Multi-beam bathymetry of the eastern part of Seamount 6. This is the westernmost studied during ANT-XXIII/4 and has not been mapped before. It appears to be one of the largest MBS. (c) Haxby Seamount (named by the ANT-XIII/4 cruise participants) has completely been mapped on the R/V N.B. Palmer cruise in 1996 and morphologically studied in detail by Feldberg (1997). (d) Combined ANT-XVIII/5a (2001) and ANT-XXIII/4 multi-beam bathymetry of Hubert Miller Seamount. This Seamount is located $\sim 40 \mathrm{~nm}$ ESE of Haxby and appears to be the largest of the MBS. (e) Combined ANT-XVI/3 (Miller and Grobe, 1996) and ANT-XXIII/4 multi-beam bathymetry of Seamount C. This seamount does not appear in the bathymetric maps derived from satellite gravity data. Note that Seamount C differs in size, high, and morphology from the other surveyed MBS guyots. The red dots with numbers mark dredge station of cruise ANT-XXIII/4 which yielded in situ volcanic rocks.

Seamount 6), which are believed to be the product of a mantle plume (e.g., Montelli et al., 2006).

The submarine base of Peter I Island was only partially surveyed prior to ANT-XXIII/4 and, except for dredge hauls directly off the coast of the island (Broch, 1927), un-sampled (Fig. 4). The island is elongated in $\mathrm{N}-\mathrm{S}$ direction and represents the top of a large volcano, which measures $\sim 65 \mathrm{~km}$ in diameter at its base and rises from the abyssal plain at $\sim 3500-4000 \mathrm{~m}$ to an elevation of $1640 \mathrm{~m}$ above sea 


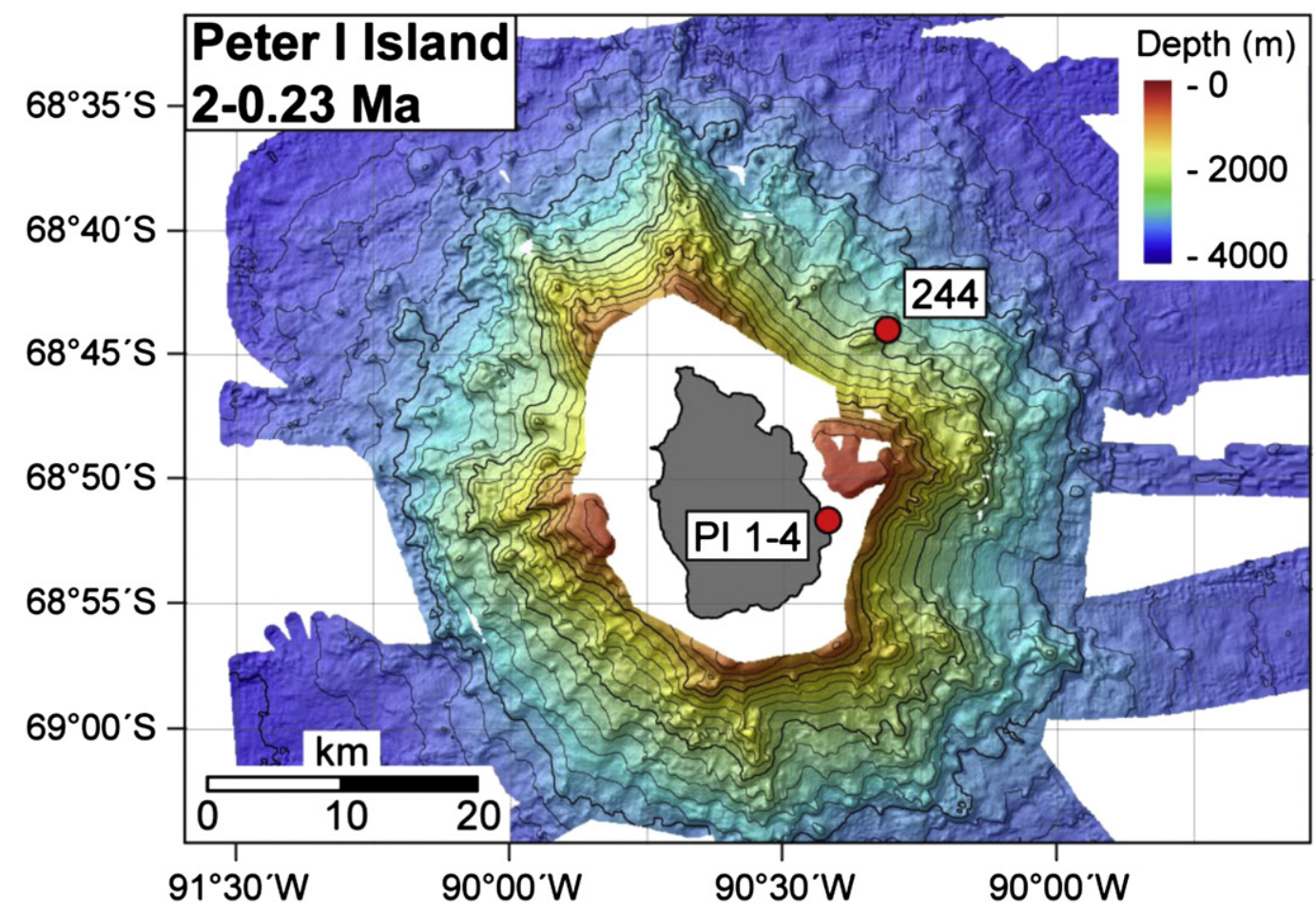

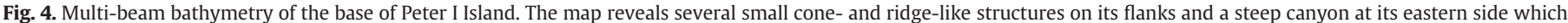

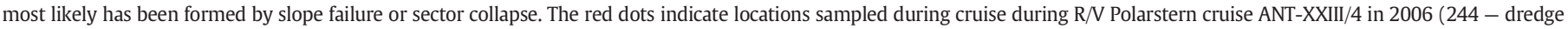
station at the eastern base of Peter I Island; PI 1-4 - subaerial samples taken on Michajlovodden Peninsula).

level. Volcanic rifts emanate from the submarine flank of the island mainly in northern and southern directions. A striking feature of Peter I Island is a c. $9 \mathrm{~km}$ wide depression in the eastern flank of its base, which most likely has been formed by a major slope failure or sector collapse.

\section{Sample background}

Volcanic rocks were recovered at five dredge stations of the main MBS edifices and associated small cones (Fig. 3b-e). In addition a single dredge haul along the northeastern submarine flank of Peter I Island has been carried out (Fig. 4). At all dredge sites discussed here, the angular shape of the rocks, freshly broken surfaces and homogeneity of rock types within a single dredge were taken as evidence for an in-situ origin (and non-ice rafted) of the rocks. Our samples represent the first in-situ volcanic rocks recovered from the MBS. A detailed description of dredge operations and recovered material is provided in chapter 7 of Gohl (2007).

At Haxby Seamount, dredge haul PS69-317-1 from the upper southern slope beneath the plateau edge contained freshly broken carbonate cemented breccias, which consist of aphyric basaltic clasts up to $8 \mathrm{~cm}$ in size (Fig. 5a). At Hubert Miller Seamount, three dredges yielded mainly lava fragments; dredge PS69-321-1 along a steep slope below the SE plateau edge gave olivine (ol)-clinopyroxene (cpx)-phyric lava Fig. 5b, dredge PS69-324-1 at the lower SE slope beneath a cone like structure provided dense feldspar (fsp)-cpx-phyric basalt lava and (carbonate) cemented Mn-encrusted volcanic breccia, and dredge PS69-325-1 obtained vesicular fsp-phyric lava from the upper southern flank. At Seamount C, vesicular ol-fsp-phyric and dense fsp-phyric pillow fragments (Fig. 5c) were dredged from a cone on the lower western flank.

At Peter I Island, a $150 \mathrm{~m}$ high ridge located in $\sim 1800 \mathrm{~m}$ water depth on the NE slope of the volcano was dredged (PS69-244-1). The rocks are predominantly vesicular pillow and sheet flow lava fragments (Fig. 5d). Both are feldspar (fsp)-phyric and have up to $1 \mathrm{~cm}$ thick, fresh, glassy rims. Vesicles are generally unfilled and only a few glassy surfaces show early stages of palagonitization. The subaerial samples from Peter I Island were taken at the Michajlovodden Peninsula (Fig. 4). They comprise vesicular lava (up to 15\% vesicles; sample PI-1), aphyric agglutinates of $\mathrm{a}>1.5 \mathrm{~m}$ thick, partially red oxidized layer outcropping in the northern part of the peninsula (sample PI-3), and part of a reddish volcanic bomb with $10-20 \%$ vesicles (sample PI-4).

Belgica Seamount is the easternmost edifice of the De Gerlache Seamount group. It is guyot-shaped and has a N-S elongated base diameter of c. $60 \times 90 \mathrm{~km}$ with a flat-topped summit at c. $400-500 \mathrm{~m}$ below sea level. Belgica was dredge-sampled during Polarstern cruise ANTXII-4 in 800 to 600 water depths (Hagedorn et al., 2007). Hagedorn et al. (2007) initially determined $\mathrm{K}-\mathrm{Ar}$ ages and major and trace element geochemistry on the recovered samples. Here we complement the existing data with $\mathrm{Sr}-\mathrm{Nd}-\mathrm{Pb}$ isotope data on a subset of newly prepared sample material.

\section{Petrography and rock classification}

The petrography of the MBS volcanics is quite uniform being slightly phyric with a few large phenocrysts of altered olivine and zoned plagioclase in a fine-grained groundmass of olivine, plagioclase and clinopyroxene. Occasionally, ilmenite and magnetite occur as accessory phases. Olivine is commonly altered to iddingsite and the latter is sometimes replaced by calcite. The groundmass is variably altered by low temperature processes ranging from hydrated glass at Haxby Seamount to replacement by secondary minerals such as zeolite and dolomite at Hubert Miller Seamount and Seamount C. The altered state of the MBS volcanic rocks is also manifested in elevated $\mathrm{H}_{2} \mathrm{O}$ contents of up to 2 wt.\% in most samples, except that samples from Dredge 324 at Hubert Miller Seamount have $<1$ wt.\% $\mathrm{H}_{2} \mathrm{O}$ and those from Seamount $\mathrm{C}$ have 3 wt.\% $\mathrm{H}_{2} \mathrm{O}$ (Table 2). $\mathrm{CO}_{2}$ contents are generally low $(<0.3 \mathrm{wt} . \%)$ and only two samples show slightly elevated $\mathrm{CO}_{2}>0.5$ wt.\%, due to secondary carbonate. Unusually high phosphorous contents were detected in 5 samples (marked with ${ }^{\text {a }}$ in Table 2) and are interpreted to reflect the presence of secondary phosphate that is, however, not detected in thin section. Only samples 


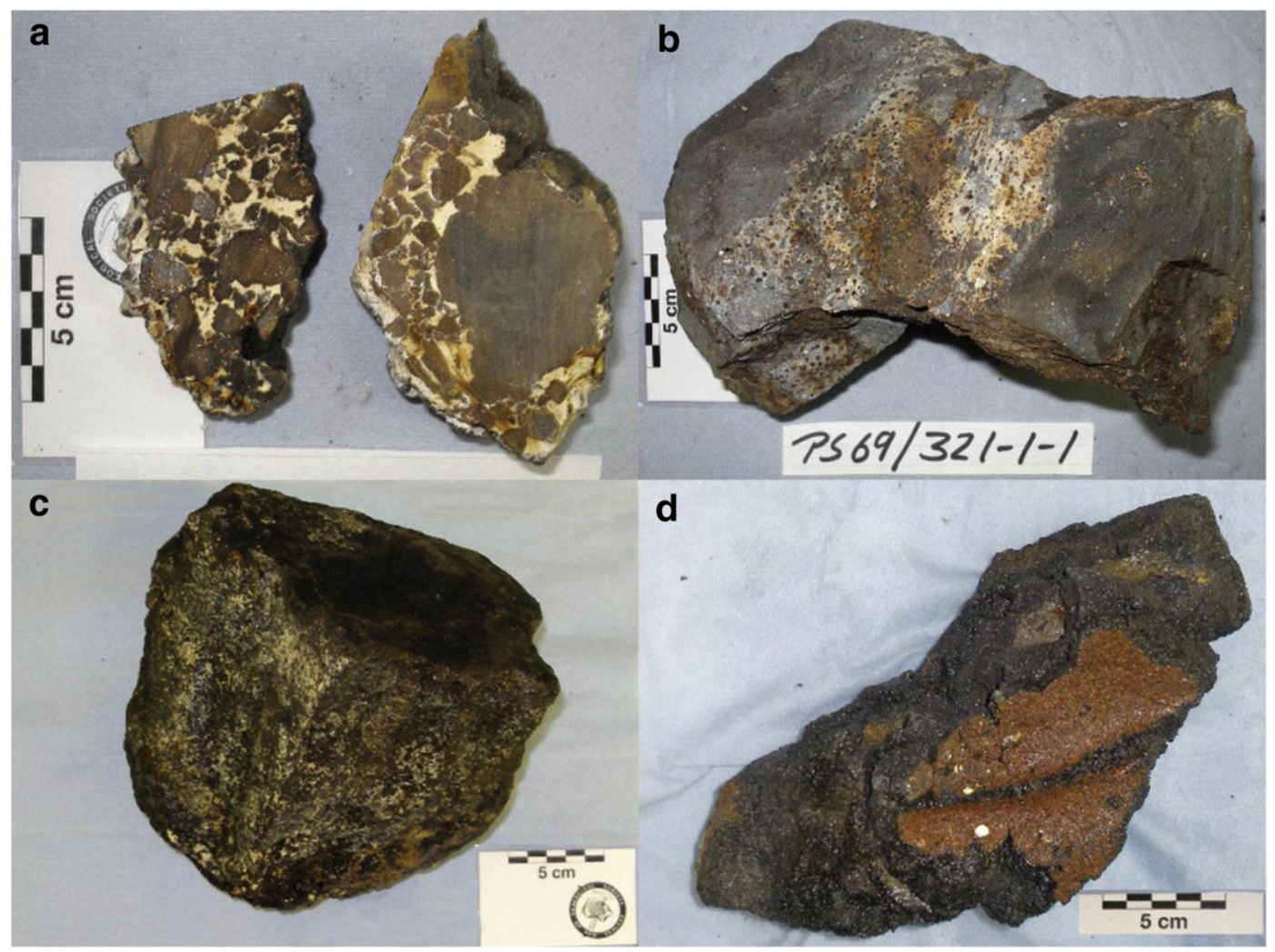

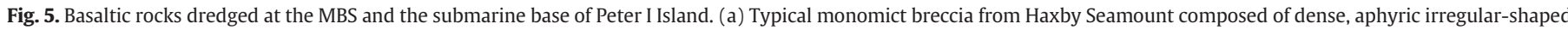

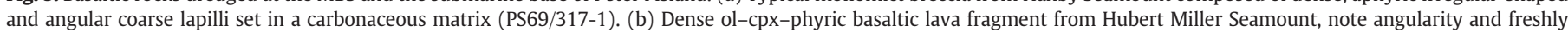

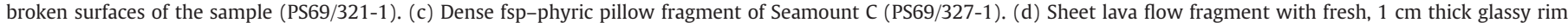
from the submarine base of Peter I Island (PS69/244-1).

with $\mathrm{P}_{2} \mathrm{O}_{5} \leq 1$ wt.\% are considered meaningful when treating the major element chemistry further below.

The submarine samples of Peter I Island are slightly porphyric with zoned plagioclase laths and small, homogeneously distributed clinopyroxene phenocrysts, set in a microcrystalline groundmass of clinopyroxene and plagioclase. Magnetite occurs as an accessory mineral and fresh glass is common. The subaerial volcanics of Peter I Island are more aphyric than those from the submarine flanks. The fine-grained crystalline groundmass of these samples contains pyroxene, plagioclase and possibly glass, and accessory minerals of magnetite, ilmenite and hematite. All samples from Peter I Island are generally very fresh as manifested by low $\mathrm{H}_{2} \mathrm{O}\left(0.3-0.9\right.$ wt.\%) and $\mathrm{CO}_{2}(<0.06$ wt.\%) contents (Table 2).

The silica content of the entire sample suite ranges from 53.1 to 45.7 wt.\% $\mathrm{SiO}_{2}$. On a total alkali vs. silica diagram (TAS; Fig. 6), the majority of the samples plots above the alkalic-sub-alkalic division line and are classified as basalts, trachybasalts and basaltic trachyandesites. All but one of MBS samples lie along an alkali basaltic differentiation trend. The samples from the submarine flank of Peter I Island are tholeiitic basalts $\left(\mathrm{SiO}_{2} \sim 49\right.$ wt.\%; $\mathrm{Na}_{2} \mathrm{O}+\mathrm{K}_{2} \mathrm{O}$ 4.1-4.3 wt.\%), whereas the subaerial samples are slightly more alkaline transitional tholeiites $\left(\mathrm{SiO}_{2} \sim 47\right.$ wt.\%; $\mathrm{Na}_{2} \mathrm{O}+\mathrm{K}_{2} \mathrm{O} 4.3-4.5$ wt.\%).

\section{Analytical results}

\section{1. ${ }^{40} \mathrm{Ar} /{ }^{39} \mathrm{Ar}$ age dating}

The ${ }^{40} \mathrm{Ar} /{ }^{39} \mathrm{Ar}$ age dating results are summarized in Table 3. Age and alteration index spectra (based on the measured ${ }^{36} \mathrm{Ar} /{ }^{37} \mathrm{Ar}$ ratios after Baksi, 2007) are shown in Fig. 7. A detailed description of the methods and the full analytical data are provided in Appendix 1.
Glasses from two hyaloclastite breccia samples at Haxby Seamount yield plateau ages of $64.2 \pm 0.9 \mathrm{Ma}$ (317-1-1gls) and of $62.3 \pm 0.4$ (317-1-2gls) and $61.2 \pm 0.5 \mathrm{Ma}$ (317-1-2gl2), slightly outside of the two sigma analytical errors. Alteration indices are relatively high even in the plateau sections ( 0.001 to 0.01 ), reflecting partial hydration of the basalt glass and uptake of atmospheric ${ }^{36} \mathrm{Ar}$.

Three samples of porphyric lava from Hubert Miller Seamount yield plagioclase step-heating plateau ages of $56.7 \pm 1.9 \mathrm{Ma}$ (321-1-2), $56.5 \pm 0.6 \mathrm{Ma}$ (325-1-2B) and 57.0 $\pm 0.9 \mathrm{Ma}$ (321-1-5). Alteration indices are high in the low-temperature heating steps indicating partial alteration of the feldspars, but systematically low in the plateau steps $(<0.0002)$ indicating degassing from little or un-altered sites. Matrix step-heating analyses from the same rock samples yield plateau age results within error of the feldspar step-heating results (321-1-2: $58.9 \pm 0.6 \mathrm{Ma}$; 321-1-5: $55.7 \pm 0.5 \mathrm{Ma}$ ), but are considered inferior with respect to scatter and alteration effects.

The matrix step-heating analysis of aphyric basalt lava sample $324-1-3$, in contrast, yields a plateau age of $3.0 \pm 0.5$ Ma. Alteration indices are high in the plateau section ( 0.003 to 0.01 ), possibly indicating a partial loss of radiogenic ${ }^{40} \mathrm{Ar}$. Nevertheless, the analysis shows that Hubert Miller Seamount comprises both Paleocene and Pliocene lavas.

The least-altered aphyric lava sample from Seamount "C" (327-1-2) yields a low-probability plateau age of $58.7 \pm 0.8 \mathrm{Ma}$, with intermediate plateau-step alteration indices ( 0.002 to 0.008 ). Fresh basaltic glass from Peter I Seamount yields plateau steps alteration indices of $<0.0009$ (244-1-1) and <0.0001 (244-1-3), and plateau ages of $1.9 \pm 0.3 \mathrm{Ma}$ $1.7 \pm 0.3$ Ma respectively.

\subsection{Major and trace elements}

A total of 19 samples from the MBS and Peter I Island were analyzed for major and trace elements compositions and the results are 
Table 2

Results of major and trace element analyses.

\begin{tabular}{|c|c|c|c|c|c|c|c|c|c|c|}
\hline & $\begin{array}{l}\text { PS69/317-1-1 } \\
\text { Haxby Smt }\end{array}$ & $\begin{array}{l}\text { PS69/317-1-1 } \\
\text { Replicate ICP-MS }\end{array}$ & $\begin{array}{l}\text { PS69/317-1-2 } \\
\text { Haxby Smt }\end{array}$ & $\begin{array}{l}\text { PS69/321-1-2 } \\
\text { Hubert Miller Smt }\end{array}$ & $\begin{array}{l}\text { PS69/321-1-4 } \\
\text { Hubert Miller Smt }\end{array}$ & $\begin{array}{l}\text { PS69/321-1-5 } \\
\text { Hubert Miller Smt }\end{array}$ & $\begin{array}{l}\text { PS69/321-1-12a } \\
\text { Hubert Miller Smt }\end{array}$ & $\begin{array}{l}\text { PS69/324-1-3 } \\
\text { Hubert Miller Smt }\end{array}$ & $\begin{array}{l}\text { PS69/324-1-4 } \\
\text { Hubert Miller Smt }\end{array}$ & $\begin{array}{l}\text { PS69/324-1-6 } \\
\text { Hubert Miller Smt }\end{array}$ \\
\hline $\mathrm{SiO}_{2}$ & 46.13 & & 42.03 & 50.22 & 46.23 & 45.95 & 50.19 & 45.80 & 52.85 & 46.74 \\
\hline $\mathrm{TiO}_{2}$ & 3.39 & & 3.57 & 1.89 & 3.59 & 3.44 & 2.09 & 2.60 & 0.85 & 3.26 \\
\hline $\mathrm{Al}_{2} \mathrm{O}_{3}$ & 16.33 & & 18.2 & 17.15 & 17.59 & 16.62 & 18.46 & 15.02 & 17.18 & 14.86 \\
\hline $\mathrm{Fe}_{2} \mathrm{O}_{3}$ & 14.81 & & 15.91 & 11.49 & 14.19 & 13.95 & 11.09 & 13.05 & 8.63 & 14.73 \\
\hline $\mathrm{MnO}$ & 0.21 & & 0.21 & 0.22 & 0.19 & 0.22 & 0.17 & 0.19 & 0.18 & 0.20 \\
\hline $\mathrm{MgO}$ & 3.46 & & 3.41 & 2.58 & 2.85 & 3.96 & 2.07 & 8.13 & 5.52 & 4.87 \\
\hline $\mathrm{CaO}$ & 7.72 & & 9.02 & 6.39 & 8.84 & 8.44 & 6.76 & 10.65 & 8.68 & 10.31 \\
\hline $\mathrm{Na}_{2} \mathrm{O}$ & 3.82 & & 3.51 & 4.57 & 3.54 & 3.53 & 4.53 & 3.29 & 3.99 & 3.65 \\
\hline $\mathrm{K}_{2} \mathrm{O}$ & 1.54 & & 0.74 & 2.61 & 2.09 & 2.05 & 2.15 & 1.04 & 1.45 & 1.24 \\
\hline $\mathrm{P}_{2} \mathrm{O}_{5}$ & 0.91 & & $1.44^{\mathrm{a}}$ & 0.73 & 0.92 & 0.79 & 0.87 & 0.48 & 0.21 & 0.54 \\
\hline $\mathrm{H}_{2} \mathrm{O}$ & 1.91 & & 2.38 & 2.23 & 1.80 & 1.86 & 2.10 & 0.74 & 0.98 & 0.82 \\
\hline $\mathrm{CO}_{2}$ & 0.06 & & 0.17 & 0.30 & 0.08 & 0.07 & 0.07 & 0.13 & 0.07 & 0.08 \\
\hline Total & 100.29 & & 100.59 & 100.38 & 101.91 & 100.88 & 100.55 & 101.12 & 100.59 & 101.30 \\
\hline $\mathrm{Rb}$ & 28.1 & 28.1 & 6.66 & 53.4 & 37.3 & 50.4 & 23.9 & 24.1 & 35.8 & 28.0 \\
\hline $\mathrm{Ba}$ & 330 & 330 & 264 & 725 & 462 & 493 & 784 & 311 & 455 & 320 \\
\hline Th & 4.79 & 4.72 & 4.60 & 6.89 & 4.57 & 4.43 & 7.31 & 2.99 & 4.72 & 3.91 \\
\hline U & 1.52 & 1.52 & 0.427 & 1.75 & 0.816 & 0.695 & 0.296 & 0.743 & 0.819 & 0.982 \\
\hline $\mathrm{Nb}$ & 70.3 & 70.6 & 68.1 & 123 & 78.5 & 77.2 & 119 & 46.0 & 78.5 & 56.6 \\
\hline $\mathrm{Ta}$ & 4.21 & 4.18 & 4.27 & 6.60 & 4.59 & 4.45 & 6.97 & 2.78 & 4.60 & 3.39 \\
\hline La & 49.6 & 48.9 & 64.4 & 76.8 & 52.4 & 51.4 & 65.9 & 32.1 & 53.1 & 38.3 \\
\hline $\mathrm{Ce}$ & 106 & 106 & 114 & 154 & 106 & 103 & 146 & 66.2 & 107 & 78.4 \\
\hline $\mathrm{Pb}$ & 2.75 & 2.35 & 2.41 & 3.81 & 2.44 & 2.65 & 3.37 & 2.47 & 2.30 & 1.89 \\
\hline $\operatorname{Pr}$ & 13.1 & 13.1 & 14.4 & 17.0 & 12.2 & 11.6 & 16.1 & 7.74 & 12.3 & 8.98 \\
\hline $\mathrm{Nd}$ & 55.6 & 55.2 & 57.6 & 63.2 & 46.0 & 44.3 & 61.6 & 30.1 & 46.5 & 35.5 \\
\hline $\mathrm{Sr}$ & 760 & 756 & 1219 & 825 & 969 & 925 & 891 & 626 & 967 & 568 \\
\hline $\mathrm{Sm}$ & 12.1 & 12.1 & 13.3 & 12.6 & 9.86 & 9.49 & 12.5 & 6.69 & 9.97 & 8.08 \\
\hline $\mathrm{Hf}$ & 8.06 & 8.02 & 8.35 & 8.83 & 6.36 & 5.94 & 9.36 & 4.30 & 6.35 & 5.55 \\
\hline $\mathrm{Zr}$ & 404 & 402 & 413 & 475 & 323 & 317 & 446 & 205 & 321 & 261 \\
\hline Eu & 3.79 & 3.75 & 4.14 & 3.92 & 3.09 & 2.91 & 4.12 & 2.19 & 3.04 & 2.49 \\
\hline $\mathrm{Gd}$ & 10.8 & 10.7 & 11.4 & 10.2 & 8.00 & 7.45 & 9.66 & 5.89 & 8.10 & 7.17 \\
\hline $\mathrm{Tb}$ & 1.45 & 1.47 & 1.56 & 1.40 & 1.05 & 0.979 & 1.29 & 0.814 & 1.02 & 1.02 \\
\hline Dy & 7.98 & 7.89 & 8.36 & 7.50 & 5.40 & 5.04 & 6.58 & 4.38 & 5.49 & 5.74 \\
\hline Ho & 1.43 & 1.46 & 1.54 & 1.33 & 0.97 & 0.92 & 1.14 & 0.787 & 0.971 & 1.02 \\
\hline $\mathrm{Y}$ & 42.3 & 42.0 & 51.6 & 43.6 & 32.5 & 31.5 & 35.5 & 25.2 & 31.6 & 31.8 \\
\hline $\mathrm{Er}$ & 3.59 & 3.72 & 3.84 & 3.47 & 2.49 & 2.31 & 2.79 & 2.07 & 2.50 & 2.66 \\
\hline $\mathrm{Tm}$ & 0.457 & 0.479 & 0.475 & 0.455 & 0.310 & 0.291 & 0.345 & 0.261 & 0.325 & 0.350 \\
\hline $\mathrm{Yb}$ & 3.13 & 3.14 & 3.84 & 3.54 & 2.57 & 2.45 & 2.76 & 2.08 & 2.49 & 2.65 \\
\hline Lu & 0.450 & 0.447 & 0.554 & 0.496 & 0.359 & 0.332 & 0.366 & 0.278 & 0.350 & 0.364 \\
\hline
\end{tabular}




\begin{tabular}{|c|c|c|c|c|c|c|c|c|c|c|}
\hline & $\begin{array}{l}\text { PS69/325-1-2a } \\
\text { Hubert Miller Smt }\end{array}$ & $\begin{array}{l}\text { PS69/325-1-2b } \\
\text { Hubert Miller Smt }\end{array}$ & $\begin{array}{l}\text { PS69/327-1-1 } \\
\text { Seamount C }\end{array}$ & $\begin{array}{l}\text { PS69/327-1-2 } \\
\text { Seamount C }\end{array}$ & $\begin{array}{l}\text { PS69/244-1-1 } \\
\text { Peter I submarine }\end{array}$ & $\begin{array}{l}\text { PS69/244-1-3 } \\
\text { Peter I submarine }\end{array}$ & $\begin{array}{l}\text { PS69/244-1-5 } \\
\text { Peter I submarine }\end{array}$ & $\begin{array}{l}\text { PS69/PI-1 } \\
\text { Peter I subaerial }\end{array}$ & $\begin{array}{l}\text { PS69/PI-3 } \\
\text { Peter I subaerial }\end{array}$ & $\begin{array}{l}\text { PS69/PI-4 } \\
\text { Peter I subaerial }\end{array}$ \\
\hline $\mathrm{SiO}_{2}$ & 47.72 & 47.72 & 41.98 & 46.00 & 49.48 & 49.09 & 49.26 & 47.79 & 47.26 & 48.15 \\
\hline $\mathrm{TiO}_{2}$ & 2.52 & 2.49 & 2.26 & 2.70 & 2.79 & 2.74 & 2.75 & 3.53 & 3.48 & 3.46 \\
\hline $\mathrm{Al}_{2} \mathrm{O}_{3}$ & 16.78 & 17.24 & 18.15 & 20.31 & 13.68 & 13.26 & 13.61 & 12.79 & 12.52 & 12.73 \\
\hline $\mathrm{Fe}_{2} \mathrm{O}_{3}$ & 11.58 & 12.02 & 8.92 & 11.30 & 12.58 & 12.55 & 12.85 & 13.48 & 13.36 & 13.03 \\
\hline $\mathrm{MnO}$ & 0.14 & 0.14 & 0.08 & 0.15 & 0.14 & 0.15 & 0.14 & 0.15 & 0.15 & 0.14 \\
\hline $\mathrm{MgO}$ & 2.54 & 1.34 & 0.97 & 1.24 & 8.18 & 9.2 & 8.55 & 9.64 & 9.86 & 9.42 \\
\hline $\mathrm{CaO}$ & 7.93 & 7.40 & 12.84 & 8.73 & 9.00 & 8.68 & 8.91 & 9.03 & 8.83 & 8.67 \\
\hline $\mathrm{Na}_{2} \mathrm{O}$ & 3.88 & 4.19 & 3.55 & 3.44 & 3.17 & 3.03 & 3.00 & 3.07 & 3.03 & 3.17 \\
\hline $\mathrm{K}_{2} \mathrm{O}$ & 2.74 & 3.24 & 1.74 & 1.38 & 1.16 & 1.08 & 1.15 & 1.37 & 1.42 & 1.47 \\
\hline $\mathrm{P}_{2} \mathrm{O}_{5}$ & $1.69^{\mathrm{a}}$ & $2.12^{\mathrm{a}}$ & $5.02^{\mathrm{a}}$ & $1.62^{\mathrm{a}}$ & 0.50 & 0.51 & 0.48 & 0.64 & 0.69 & 0.78 \\
\hline $\mathrm{H}_{2} \mathrm{O}$ & 2.12 & 2.13 & 2.92 & 3.03 & 0.86 & 0.87 & 0.94 & 0.28 & 0.45 & 0.38 \\
\hline $\mathrm{CO}_{2}$ & 0.59 & 0.18 & 0.56 & 0.24 & 0.05 & 0.05 & 0.06 & 0.04 & 0.04 & 0.04 \\
\hline Total & 100.23 & 100.21 & 98.99 & 100.14 & 101.59 & 101.21 & 101.70 & 101.81 & 101.09 & 101.44 \\
\hline $\mathrm{Rb}$ & 90.1 & 57.3 & 27.2 & 21.5 & 20.3 & 19.8 & 19.2 & 23.9 & 26.5 & 26.3 \\
\hline $\mathrm{Ba}$ & 469 & 480 & 404 & 427 & 240 & 228 & 226 & 308 & 315 & 332 \\
\hline Th & 6.93 & 7.02 & 5.21 & 5.06 & 2.85 & 2.68 & 2.57 & 3.53 & 3.74 & 3.78 \\
\hline U & 1.34 & 1.33 & 1.78 & 1.43 & 0.887 & 0.725 & 0.704 & 0.920 & 0.984 & 1.02 \\
\hline $\mathrm{Nb}$ & 95.6 & 96.8 & 55.6 & 58.7 & 30.2 & 29.4 & 28.9 & 48.5 & 48.7 & 50.6 \\
\hline $\mathrm{Ta}$ & 5.38 & 5.44 & 3.48 & 3.58 & 1.88 & 1.83 & 1.76 & 2.82 & 2.89 & 2.90 \\
\hline La & 73.5 & 73.8 & 66.2 & 44.6 & 27.2 & 26.7 & 26.1 & 38.0 & 40.3 & 43.1 \\
\hline $\mathrm{Ce}$ & 141 & 144 & 80.4 & 84.5 & 58.5 & 57.1 & 55.6 & 80.9 & 85.2 & 92.4 \\
\hline $\mathrm{Pb}$ & 3.38 & 3.21 & 3.07 & 2.24 & 2.30 & 2.26 & 2.22 & 2.26 & 2.46 & 2.31 \\
\hline $\operatorname{Pr}$ & 16.3 & 16.3 & 10.4 & 9.36 & 7.49 & 7.20 & 6.95 & 10.2 & 10.4 & 11.4 \\
\hline $\mathrm{Nd}$ & 62.4 & 62.3 & 39.0 & 35.6 & 32.7 & 30.8 & 29.2 & 43.1 & 43.6 & 48.5 \\
\hline $\mathrm{Sr}$ & 674 & 717 & 811 & 843 & 624 & 622 & 632 & 797 & 804 & 871 \\
\hline $\mathrm{Sm}$ & 12.9 & 13.3 & 8.09 & 7.89 & 7.57 & 7.54 & 7.48 & 9.80 & 10.2 & 11.0 \\
\hline $\mathrm{Hf}$ & 7.99 & 8.02 & 4.99 & 5.37 & 5.22 & 5.19 & 5.03 & 7.03 & 7.42 & 7.59 \\
\hline $\mathrm{Zr}$ & 412 & 417 & 250 & 258 & 233 & 230 & 227 & 315 & 326 & 344 \\
\hline Eu & 3.59 & 3.56 & 2.45 & 2.49 & 2.43 & 2.48 & 2.39 & 3.14 & 3.21 & 3.52 \\
\hline Gd & 10.9 & 10.9 & 7.78 & 6.87 & 6.78 & 6.55 & 6.38 & 8.50 & 8.63 & 9.61 \\
\hline $\mathrm{Tb}$ & 1.48 & 1.41 & 1.07 & 0.957 & 0.874 & 0.882 & 0.854 & 1.14 & 1.13 & 1.19 \\
\hline Dy & 7.39 & 7.51 & 6.32 & 5.30 & 4.69 & 4.54 & 4.40 & 5.70 & 5.52 & 5.85 \\
\hline Ho & 1.35 & 1.36 & 1.33 & 0.979 & 0.792 & 0.737 & 0.706 & 0.924 & 0.894 & 0.963 \\
\hline Y & 48.7 & 46.1 & 66.5 & 32.0 & 22.5 & 21.6 & 21.6 & 24.9 & 24.9 & 25.7 \\
\hline $\mathrm{Er}$ & 3.50 & 3.52 & 3.71 & 2.70 & 1.83 & 1.72 & 1.73 & 2.14 & 2.05 & 2.14 \\
\hline $\mathrm{Tm}$ & 0.458 & 0.449 & 0.509 & 0.349 & 0.226 & 0.207 & 0.204 & 0.255 & 0.246 & 0.256 \\
\hline $\mathrm{Yb}$ & 3.63 & 3.54 & 4.21 & 2.72 & 1.53 & 1.50 & 1.49 & 1.58 & 1.54 & 1.56 \\
\hline $\mathrm{Lu}$ & 0.515 & 0.506 & 0.674 & 0.377 & 0.192 & 0.193 & 0.186 & 0.206 & 0.209 & 0.203 \\
\hline
\end{tabular}




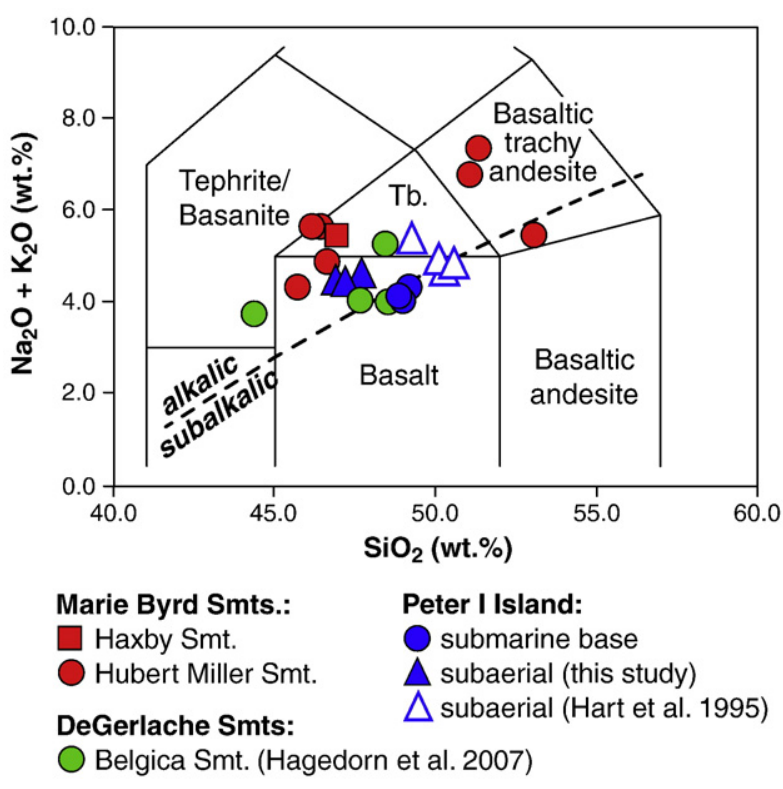

Fig. 6. Total alkali versus $\mathrm{SiO}_{2}$ diagram illustrating the alkali basaltic to basaltic trachyandesitic composition of most samples from MBS, Peter I Island, and Belgica Seamount. Subdivision between alkalic and sub-alkaline rock suites is after Irvine and Baragar (1971). All data are normalized to a $100 \%$ volatile free basis. Samples displaying unusual high phosphor contents are not shown in this diagram (cf. Table 2). Tb - Trachybasalt.

shown in Table 2. Descriptions of methods and uncertainties are given in Appendix 1. A full table with sample locations, radiometric ages and geochemical data is provided in Table A4 of the Appendix. The majority of MBS samples are fairly evolved ( 8 to $2 \mathrm{wt} . \% \mathrm{MgO}$ ), whereas samples from Peter I Island are more primitive and cluster between 10 and 8 wt.\% $\mathrm{MgO} . \mathrm{Al}_{2} \mathrm{O}_{3}$ shows a good negative correlation with decreasing $\mathrm{MgO}$, suggesting fractionation of pyroxene and olivine. In the most evolved MBS lavas ( $<3$ wt.\% $\mathrm{MgO}$ ), $\mathrm{FeOt}$ and $\mathrm{TiO}_{2}$ significantly decrease which may reflect fractionation of ilmenite in late stage melts. Subaerial and submarine samples of Peter I Island exhibit small compositional differences. The submarine samples have higher $\mathrm{SiO}_{2}$ and $\mathrm{Al}_{2} \mathrm{O}_{3}$ and slightly lower $\mathrm{MgO}$, FeOt and $\mathrm{TiO}_{2}$ contents than the subaerial samples.

Trace elements patterns of the MBS are typical for ocean islands basalts (OIB; Fig. 8a) with characteristic troughs for $\mathrm{Pb}$ and $\mathrm{K}$ and strong enrichments for $\mathrm{Nb}$ and Ta relative to primitive mantle. The $\mathrm{Nb}$ and Ta enrichments are most pronounced in samples from Hubert Miller Seamount while Haxby Seamount and Seamount $C$ are less enriched in the most incompatible elements (Rb, Ba and Th). All MBS samples show strong enrichment of the light REE (LREE) relative to the heavy REE (HREE) (see Fig. 8c), suggesting small degrees of partial melting while differentiation of the HREE indicates melting within the garnet stability field ( $>70-80 \mathrm{~km})$.
The new trace element data from Peter I Island also display trace element patterns similar to OIB (Fig. 8b) that compares well with the data of Prestvik et al. (1990) and Hart et al. (1995). Overall the subaerial samples are slightly more enriched in incompatible elements than the submarine sample but show similar HREE abundances (Fig. 8d), which is consistent with lower degrees of melting for the subaerial lavas. In contrast to the MBS, Peter I Island samples are slightly less enriched in LREE and the most incompatible elements ( $\mathrm{Rb}$ through $\mathrm{Ta}$ ) and show lower La/Sm ratios (Fig. 9a), indicating higher degrees of partial melting than observed for the MBS. Notably the LREE are more strongly enriched relative to the HREE through a more pronounced HREE depletion. The higher $(\mathrm{Sm} / \mathrm{Yb}) \mathrm{n}$ ratios of the Peter I Island melts suggest that their source had a higher garnet content (Fig. 9b).

\section{3. $\mathrm{Sr}-\mathrm{Nd}-\mathrm{Pb}-\mathrm{Hf}$ isotopes}

$\mathrm{Sr}-\mathrm{Nd}-\mathrm{Pb}-\mathrm{Hf}$ isotopic ratios of representative samples from the MBS, Belgica Seamount, and Peter I Island are shown in Table 4. Descriptions of analytical methods and accuracy along with initial isotopic ratios are given in Appendix 1 and Table A4. Figs. 10 and 11 compare the new MBS, Peter I Island and Belgica Seamount isotope data with data of West Antarctic volcanic rocks, related to the WARS (for data sources see figure captions) and the Hikurangi Seamounts (Hoernle et al., 2010). Excluding two samples with anomalously high ${ }^{87} \mathrm{Sr} /{ }^{86} \mathrm{Sr}$ isotope ratios that may have been affected by seawater alteration, the MBS samples form a crude negative array on the $\mathrm{Sr}-\mathrm{Nd}$ isotope diagram (Fig. 10). The samples from Seamount $C$ have the most radiogenic $\mathrm{Nd}$ and least radiogenic $\mathrm{Sr}$ isotope ratios and fall between Pacific MORB and the high ${ }^{238} \mathrm{U} /{ }^{204} \mathrm{~Pb}$ (HIMU) mantle endmember. Samples from Hubert Miller Seamount have the least radiogenic Nd isotope ratios and trend vaguely towards an enriched mantle (EM) type component (Fig. 10). The Belgica samples plot within the Pacific MORB field and the Peter I Island samples lie within the published field for this island (Prestvik et al., 1990; Hart et al., 1995) and are displaced to slightly more radiogenic $\mathrm{Sr}$ and less radiogenic Nd isotope ratios i.e. to faintly more EM flavored compositions than the majority of Hubert Miller Seamount samples. In Pb-Pb isotope space (Fig. 11a), the MBS volcanic rocks do not form a simple two component mixing array as the majority of samples extends from a HIMU-type component with radiogenic $\mathrm{Pb}$ towards enriched mantle one (EMI) while two samples having significantly lower ${ }^{207} \mathrm{~Pb} /{ }^{204} \mathrm{~Pb}$ which displaces them towards the extension of the Pacific MORB field. Sample 324-1-4 from Hubert Miller Seamount has the least radiogenic $\mathrm{Pb}$ composition of all MBS and plots above the Pacific MORB field away from the main MBS array while samples from Haxby Seamount possess the most radiogenic $\mathrm{Pb}$ composition. The Belgica Seamount samples plot near the unradiogenic end of the main MBS field in $\mathrm{Pb}-\mathrm{Pb}$ isotope space (Fig. 11a) but possess more radiogenic ${ }^{143} \mathrm{Nd} /{ }^{144} \mathrm{Nd}$ compositions than the MBS (Fig. 11b). The majority of MBS samples and all Belgica

Table 3

${ }^{40} \mathrm{Ar} /{ }^{39} \mathrm{Ar}$ step heating analyses results.

\begin{tabular}{|c|c|c|c|c|c|c|c|}
\hline Seamount & Sample ID PS69- & Analysis ID & Dated material & $\begin{array}{l}\text { Plateau } \pm 2 \text { sigma age } \\
\text { (Ma) }\end{array}$ & ${ }^{39} \mathrm{Ar}$ fraction & MSWD & Probability \\
\hline \multirow[t]{3}{*}{ Haxby } & 317-1-1 & gls & Glass & $64.7 \pm 0.8$ & 63.1 & 0.95 & 0.46 \\
\hline & $317-1-2$ & gls & Glass & $62.3 \pm 0.4$ & 56.8 & 0.99 & 0.44 \\
\hline & $317-1-2$ & gl2 & Glass & $61.2 \pm 0.5$ & 72.9 & 1.19 & 0.27 \\
\hline \multirow{6}{*}{ Hubert Miller } & $321-1-2$ & fss & Plag & $56.7 \pm 1.9$ & 73.9 & 0.61 & 0.72 \\
\hline & $321-1-2$ & $\mathrm{mx} 2$ & Matrix & $58.9 \pm 0.6$ & 95.6 & 1.10 & 0.34 \\
\hline & $321-1-5$ & fss & Plag & $57.0 \pm 0.9$ & 58.4 & 1.30 & 0.23 \\
\hline & $321-1-5$ & $m x 2$ & Matrix & $55.7 \pm 0.5$ & 63.5 & 0.78 & 0.45 \\
\hline & $325-1-2 B$ & fss & Plag & $56.5 \pm 0.6$ & 61.1 & 1.20 & 0.30 \\
\hline & $324-1-3$ & $\mathrm{mxs}$ & Matrix & $3.0 \pm 0.5$ & 84.6 & 1.30 & 0.21 \\
\hline “C” & $327-1-2$ & $\mathrm{mx} 2$ & Matrix & $58.7 \pm 0.8$ & 55.7 & 1.90 & 0.04 \\
\hline \multirow[t]{2}{*}{ Peter $\mathrm{I}^{\mathrm{a}}$} & 244-1-1 & gls & Glass & $1.9 \pm 0.3$ & 83.8 & 1.03 & 0.41 \\
\hline & $244-1-3$ & $\mathrm{gl} 2$ & Glass & $1.7 \pm 0.3$ & 96.4 & 0.58 & 0.87 \\
\hline
\end{tabular}

a Dated samples from Peter I Island are dredge samples from its submarine base. 
Table 4

$\mathrm{Sr}-\mathrm{Nd}-\mathrm{Pb}-\mathrm{Hf}-\mathrm{Isotope}$ analyses.

\begin{tabular}{|c|c|c|c|c|c|c|c|c|c|c|c|c|}
\hline & ${ }^{87} \mathrm{Sr} /{ }^{86} \mathrm{Sr}$ & 2 sigma & ${ }^{143} \mathrm{Nd} /{ }^{144} \mathrm{Nd}$ & 2 sigma & ${ }^{206} \mathrm{~Pb} /{ }^{204} \mathrm{~Pb}$ & 2 sigma & ${ }^{207} \mathrm{~Pb} /{ }^{204} \mathrm{~Pb}$ & 2 sigma & ${ }^{208} \mathrm{~Pb} /{ }^{204} \mathrm{~Pb}$ & 2 sigma & ${ }^{176} \mathrm{Hf} /{ }^{177} \mathrm{Hf}$ & 2 sigma \\
\hline \multicolumn{13}{|l|}{ Marie Byrd Smts. } \\
\hline PS69/317-1-1 & 0.703093 & 0.000003 & 0.512885 & 0.000003 & 20.7725 & 0.0015 & 15.7739 & 0.0016 & 40.1472 & 0.0056 & 0.282871 & 0.000005 \\
\hline PS69/317-1-2 & 0.704186 & 0.000003 & 0.512881 & 0.000003 & 20.4116 & 0.0020 & 15.7561 & 0.0022 & 39.9679 & 0.0075 & 0.282875 & 0.000004 \\
\hline PS69/321-1-2 & 0.703384 & 0.000003 & 0.512798 & 0.000003 & 20.2467 & 0.0016 & 15.7229 & 0.0017 & 40.0393 & 0.0057 & 0.282879 & 0.000003 \\
\hline PS69/321-1-4 & 0.703277 & 0.000002 & 0.512806 & 0.000002 & 20.1075 & 0.0006 & 15.7153 & 0.0006 & 39.9521 & 0.0018 & 0.282880 & 0.000004 \\
\hline PS69/321-1-5 & 0.703335 & 0.000002 & 0.512816 & 0.000003 & 20.1005 & 0.0008 & 15.7160 & 0.0008 & 39.9815 & 0.0028 & & \\
\hline PS69/321-1-12a & 0.703230 & 0.000003 & 0.512811 & 0.000003 & 19.9595 & 0.0008 & 15.7082 & 0.0009 & 39.9274 & 0.0028 & 0.282875 & 0.000004 \\
\hline PS69/324-1-3 & 0.703094 & 0.000003 & 0.512906 & 0.000003 & 19.6713 & 0.0011 & 15.6140 & 0.0013 & 39.5216 & 0.0044 & 0.282787 & 0.000007 \\
\hline PS69/324-1-4 & 0.704027 & 0.000003 & 0.512881 & 0.000003 & 18.7063 & 0.0006 & 15.6189 & 0.0007 & 38.4900 & 0.0020 & 0.282877 & 0.000004 \\
\hline PS69/324-1-4 & 0.704043 & 0.000003 & 0.512870 & 0.000003 & 18.7110 & 0.0006 & 15.6184 & 0.0007 & 38.4973 & 0.0019 & & \\
\hline PS69/324-1-6 & 0.703108 & 0.000003 & 0.512899 & 0.000003 & 19.8645 & 0.0009 & 15.6339 & 0.0009 & 39.7163 & 0.0027 & 0.283003 & 0.000004 \\
\hline PS69/324-1-6 & & & & & 19.8661 & 0.0013 & 15.6331 & 0.0014 & 39.7173 & 0.0048 & & \\
\hline PS69/325-1-2a & 0.703502 & 0.000003 & 0.512809 & 0.000003 & 20.1218 & 0.0008 & 15.7193 & 0.0006 & 39.9100 & 0.0016 & 0.282862 & 0.000004 \\
\hline PS69/325-1-2b & 0.703417 & 0.000002 & 0.512817 & 0.000003 & 20.0871 & 0.0008 & 15.7180 & 0.0006 & 39.8863 & 0.0017 & & \\
\hline PS69/327-1-1 & 0.702888 & 0.000003 & 0.512913 & 0.000006 & 19.8152 & 0.0010 & 15.6835 & 0.0010 & 39.2970 & 0.0031 & 0.282927 & 0.000004 \\
\hline PS69/327-1-2 & 0.702805 & 0.000003 & 0.512918 & 0.000009 & 19.8530 & 0.0008 & 15.6903 & 0.0008 & 39.3447 & 0.0024 & & \\
\hline PS69/327-1-2 ${ }^{\mathrm{d}}$ & 0.702831 & 0.000003 & 0.512927 & 0.000004 & & & & & & & & \\
\hline \multicolumn{13}{|l|}{ De Gerlache Smts. } \\
\hline PS-2693-1_(1) ${ }^{\mathrm{e}}$ & 0.703015 & 0.000005 & 0.512967 & 0.000002 & 19.8515 & 0.0021 & 15.6878 & 0.0018 & 39.5057 & 0.0049 & & \\
\hline PS-2693-1_(2) & 0.703023 & 0.000005 & 0.512966 & 0.000003 & 19.8376 & 0.0025 & 15.6795 & 0.0021 & 39.4705 & 0.0056 & & \\
\hline PS-2693-1_(3) & 0.703029 & 0.000005 & 0.512966 & 0.000003 & 19.8278 & 0.0032 & 15.6804 & 0.0027 & 39.4777 & 0.0063 & & \\
\hline PS-2693-1_(4) & 0.703029 & 0.000004 & 0.512957 & 0.000003 & 19.9238 & 0.0037 & 15.6834 & 0.0030 & 39.4845 & 0.0081 & & \\
\hline PS-2693-1_(5) ${ }^{\mathrm{e}}$ & 0.702998 & 0.000005 & 0.512983 & 0.000004 & 19.7441 & 0.0025 & 15.6641 & 0.0024 & 39.3550 & 0.0069 & & \\
\hline PS-2693-1_(6) ${ }^{\mathrm{e}}$ & 0.702994 & 0.000005 & 0.512975 & 0.000003 & 19.7447 & 0.0016 & 15.6601 & 0.0012 & 39.3438 & 0.0032 & & \\
\hline \multicolumn{13}{|l|}{ Peter I Island } \\
\hline PS69/244-1-1 & 0.703748 & 0.000003 & 0.512759 & 0.000002 & 19.2360 & 0.0015 & 15.7437 & 0.0017 & 39.3779 & 0.0056 & 0.282798 & 0.000003 \\
\hline PS69/244-1-3 & 0.703752 & 0.000003 & 0.512750 & 0.000003 & 19.2517 & 0.0006 & 15.7520 & 0.0006 & 39.4162 & 0.0019 & & \\
\hline PS69/PI- $1^{\mathrm{f}}$ & 0.703759 & 0.000005 & 0.512805 & 0.000002 & 19.3013 & 0.0012 & 15.7216 & 0.0010 & 39.3230 & 0.0026 & & \\
\hline PS69/PI-3 & 0.703837 & 0.000002 & 0.512782 & 0.000002 & 19.3015 & 0.0007 & 15.7409 & 0.0006 & 39.3865 & 0.0015 & & \\
\hline PS69/PI-4 & 0.703871 & 0.000002 & 0.512775 & 0.000003 & 19.3244 & 0.0007 & 15.7456 & 0.0006 & 39.4265 & 0.0014 & & \\
\hline
\end{tabular}

d Replicate analyses.

e ${ }^{87} \mathrm{Sr} /{ }^{86} \mathrm{Sr}$ determined on MAT262 TIMS.

${ }^{\mathrm{f}} \mathrm{Pb}$ isotope ratios without $\mathrm{Pb} \mathrm{DS}$.

Seamount samples largely overlap with the fields of the West Antarctic volcanics and the Hikurangi Seamounts (Fig. 11). The Peter I Island samples overlap the published data from this island and have $\mathrm{Pb}$ isotope compositions near the enriched mantle two (EMII) component.

The above mixing relations are also seen in co-variations of ${ }^{206} \mathrm{~Pb} /{ }^{204} \mathrm{~Pb}$ versus ${ }^{143} \mathrm{Nd} /{ }^{144} \mathrm{Nd}$ (Fig. 11b) and $\varepsilon \mathrm{Nd}$ versus $\varepsilon \mathrm{Hf}$ (Fig. 12). On the $\mathrm{Pb}$ vs Nd isotope diagram, it is clear that at least three distinct components are required in the source of the MBS seamounts. Haxby Seamount has radiogenic $\mathrm{Pb}$ and intermediate $\mathrm{Nd}$ isotope ratios, similar to the HIMU mantle endmember. Seamount $\mathrm{C}$ and two Hubert Miller Seamount samples have less radiogenic $\mathrm{Pb}$ and intermediate Nd, trending toward Pacific MORB (or depleted mantle = DM). The remaining Hubert Miller seamount samples except sample 324-1-4 have radiogenic $\mathrm{Pb}$ but the least radiogenic $\mathrm{Nd}$, so that they are somewhat displaced toward EM like compositions. On the $\mathrm{Nd}-\mathrm{Hf}$ isotope diagram, the MBS seamounts show a relatively restricted range in Nd but a large range in Hf isotope ratios that fall between Pacific MORB (DM) and the HIMU and EM mantle endmembers. The Belgica Seamount samples have the most MORB-like compositions in Nd, but their ${ }^{206} \mathrm{~Pb} /{ }^{204} \mathrm{~Pb}$ isotopic compositions are more radiogenic than commonly found in MORB. The Peter I Island samples have a clear EMII-type isotope signal with respect to $\mathrm{Pb}$ while $\mathrm{Sr}, \mathrm{Nd}$ and $\mathrm{Hf}$ isotopes are just EM indicative.

\section{Discussion}

7.1. Spatial distribution of Cenozoic volcanism in the Amundsen Sea and Bellingshausen Sea

${ }^{40} \mathrm{Ar} /{ }^{39} \mathrm{Ar}$ dating of six samples from the MBS yielded Early Cenozoic ages ranging from 64 to $57 \mathrm{Ma}$. A clear spatial age progression between the three dated MBS is not observed. The oldest ages are from Haxby Seamount in the west (64-61 Ma) and clearly younger ages are from Hubert Miller Seamount to the east ( $57 \mathrm{Ma}$, three feldspar ages). Seamount C, the easternmost seamount, yielded an intermediate age (59 Ma), but this matrix age with a very low probability should be treated with caution. The Pliocene age of $3.0 \pm 0.5 \mathrm{Ma}$ determined for sample 324-1-3 was collected right beneath a small volcanic cone along the upper slope of Hubert Miller Seamount (Fig. 3d) and most likely represents the age of this cone. Similar cones are scattered on the plateau and slopes of all mapped MBS (cf. Fig. 3), indicating widespread and possibly long-lasting low volume post-erosional volcanism, as has been observed at other seamount provinces worldwide (e.g., Hoernle et al., 2004; Geldmacher et al., 2005; Hoernle et al., 2010).

Assuming that the ${ }^{40} \mathrm{Ar} /{ }^{39} \mathrm{Ar}$ ages obtained at the three MBS are close (within a few million years) to the time when these islands were eroded and submerged below sea-level, a minimum subsidence rate can be calculated for each seamount taking the age and present water depth of the plateau of the seamount into account. Seamount $\mathrm{C}$, the smallest and deepest edifice, displays the highest subsidence rate of $\sim 41 \mathrm{~m} / \mathrm{Ma}$ if it is actually a guyot. In contrast, the larger Haxby and Hubert Miller Seamounts both yield minimum subsidence rates of $\sim 28 \mathrm{~m} / \mathrm{Ma}$ despite their apparent age difference of $\sim 5 \mathrm{Ma}$. We note that the plateau edges of the westernmost Seamounts 6 and 9 lie at roughly similar water depth (1600-1350 m, Table 1$)$ as observed for Haxby and Hubert Miller Seamounts (1800-1200 m), which in turn may indicate a comparable subsidence history provided similarities in lithospheric age and structure west of Haxby Seamount as well as analogous formation ages of $60 \pm 5 \mathrm{Ma}$.

The new ages ( $1.9 \pm 0.3 \mathrm{Ma}$ to $1.7 \pm 0.3 \mathrm{Ma})$ for samples from the eastern submarine flank of Peter I Island are significantly older 

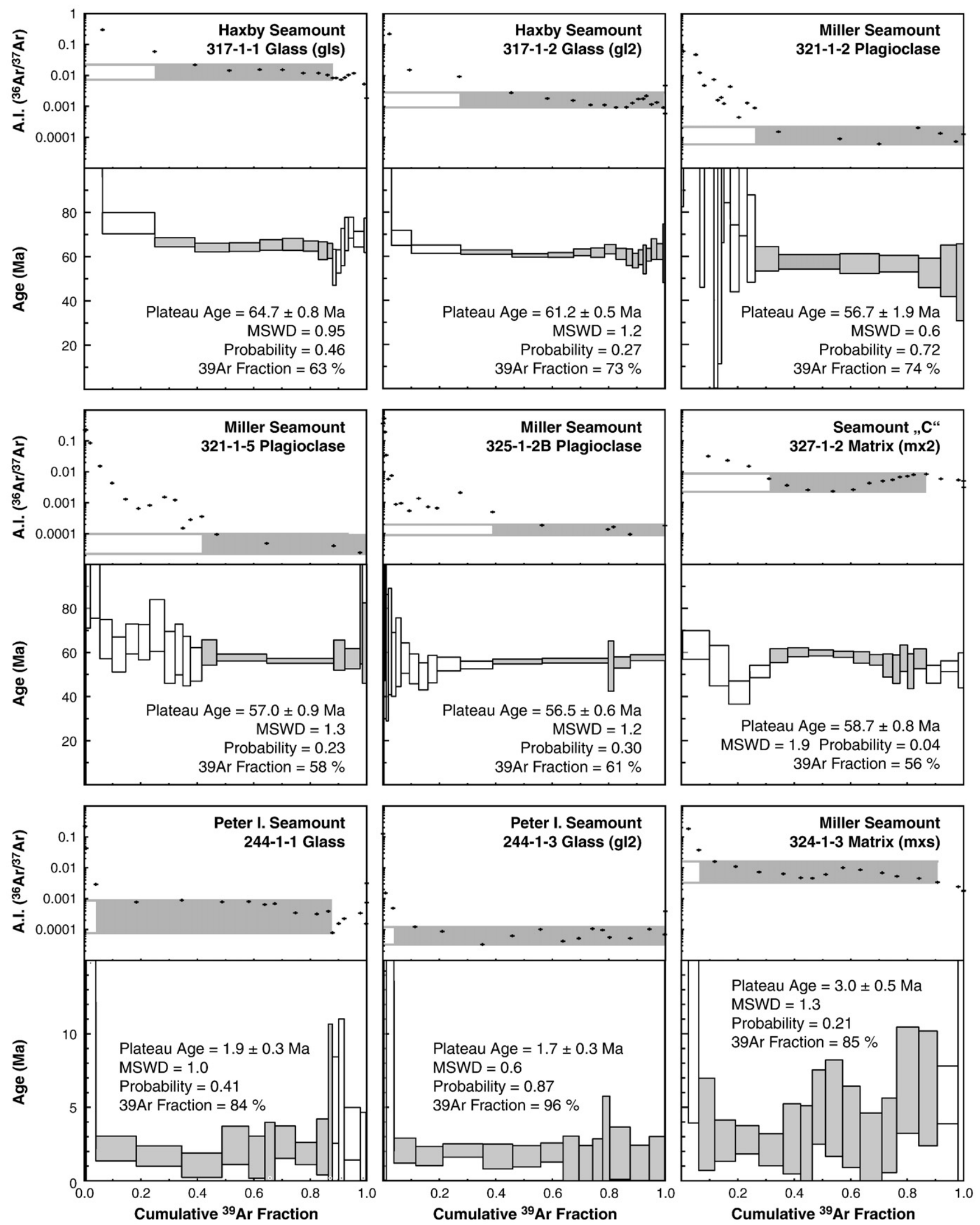

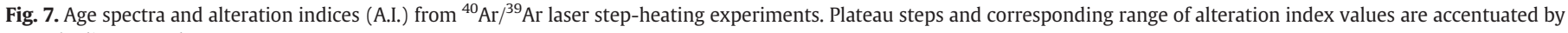
gray shading. Stated errors are $\pm 2 \sigma$. 

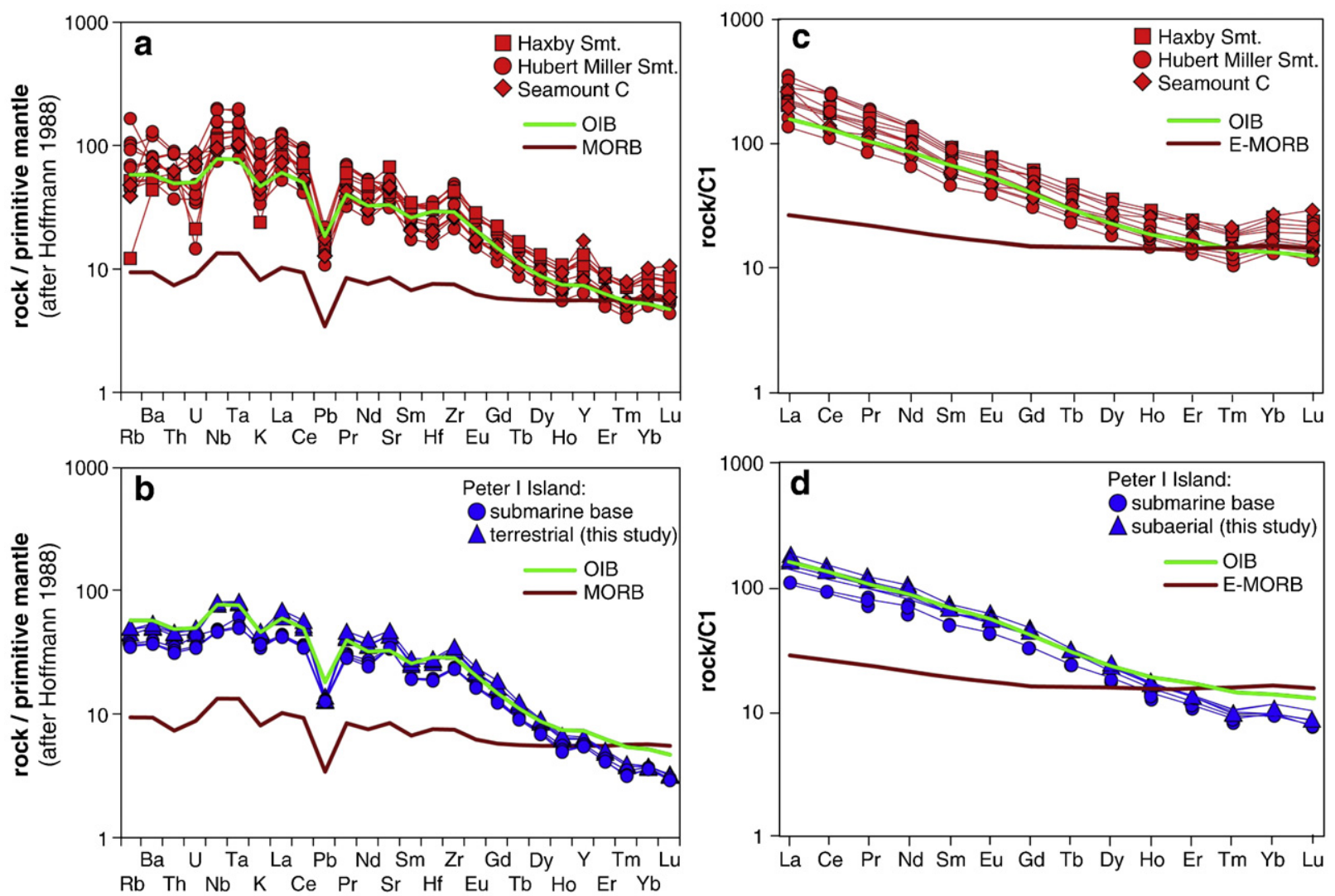

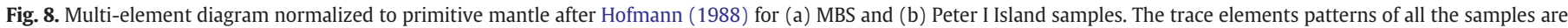

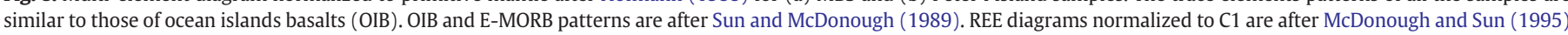
for (c) MBS and (d) Peter I Island samples.

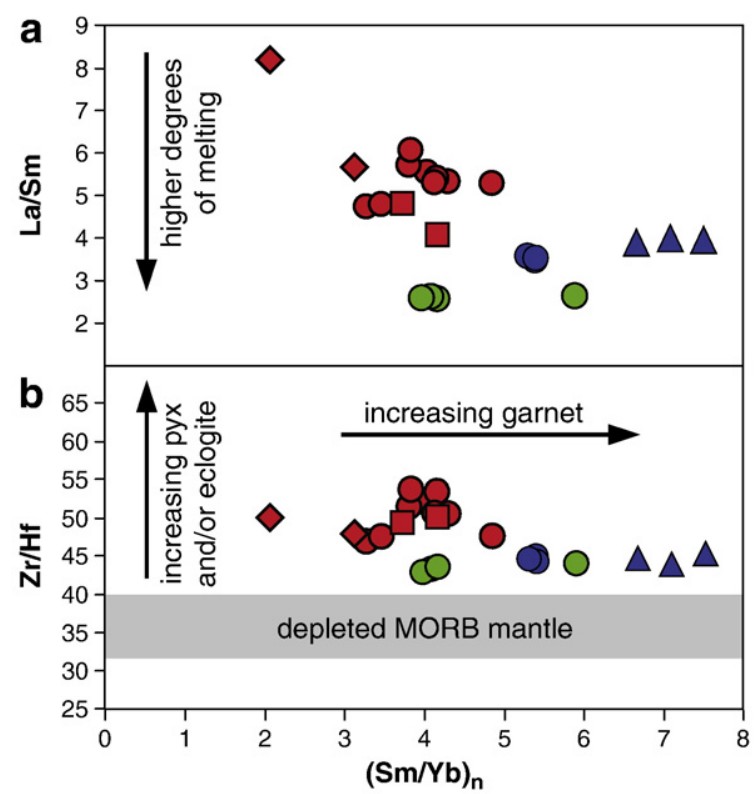

Haxby Smt.

Hubert Miller Smt.

Seamount C

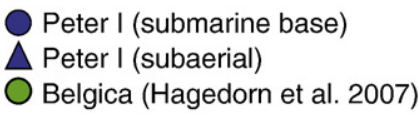

Fig. 9. $(\mathrm{Sm} / \mathrm{Yb}) \mathrm{n}$ ( $\mathrm{n}=$ normalized to primitive mantle after Hofmann, 1988) versus (a) $\mathrm{La} / \mathrm{Sm}$ and (b) $\mathrm{Zr} / \mathrm{Hf}$ ratios. Lower La/Sm ratios indicate slightly higher degrees of partial melting for Peter I Island and Belgica Seamount than for MBS. Residual garnet and pyroxene and/or eclogite in the magma source is indicated by high $(\mathrm{Sm} / \mathrm{Yb})_{n}$ ratios of 2 to 8 and relatively high $\mathrm{Zr} / \mathrm{Hf}$ ratios $(>40)$, respectively. $\mathrm{Zr} / \mathrm{Hf}$ ratios for depleted MORB mantle (32-40) are after Salters and Stracke (2004) and Workman and Hart (2005).

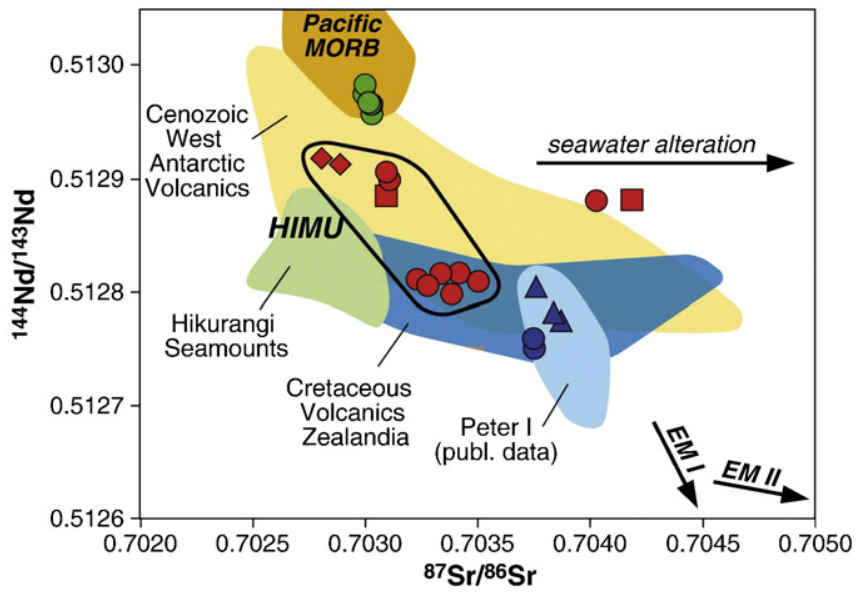

Fig. 10. ${ }^{87} \mathrm{Sr} /{ }^{86} \mathrm{Sr}$ versus ${ }^{143} \mathrm{Nd} /{ }^{144} \mathrm{Nd}$ isotope correlation diagram for MBS, Peter I Island, and Belgica Seamount samples. Symbols are as in Fig. 9. The field for West Antarctic volcanics is defined by data of the WARS (Rocholl et al., 1995; Rocchi et al., 2002a), the Jones Mountains in Ellsworth Land (Hart et al., 1995), and the Marie Byrd Land Volcanic Province (Hart et al., 1997; Panter et al., 1997, 2000), which extends along the Pacific margin of Marie Byrd Land. Most authors consider the volcanism at the Marie Byrd Land Volcanic Province and Jones Mountains as related to the WARS (e.g., Hart et al., 1995, 1997; Panter et al., 2000). The field for the Hikurangi Seamounts is based on data by Hoernle et al. (2010), published data for Peter I Island comprise analyses of subaerial basaltic lavas from Prestvik et al. (1990) and Hart et al. (1995). The field for Cretaceous volcanics of New Zealand is based on Tappenden (2003); Panter et al. (2006) and McCoy-West et al. (2010). HIMU, EM I, and EM II are after Zindler and Hart (1986) and Hart et al. (1992). Fields for Pacific MORB are from PetDB (http:// www.earthchem.org/petdb) based on analyses of fresh glass. 


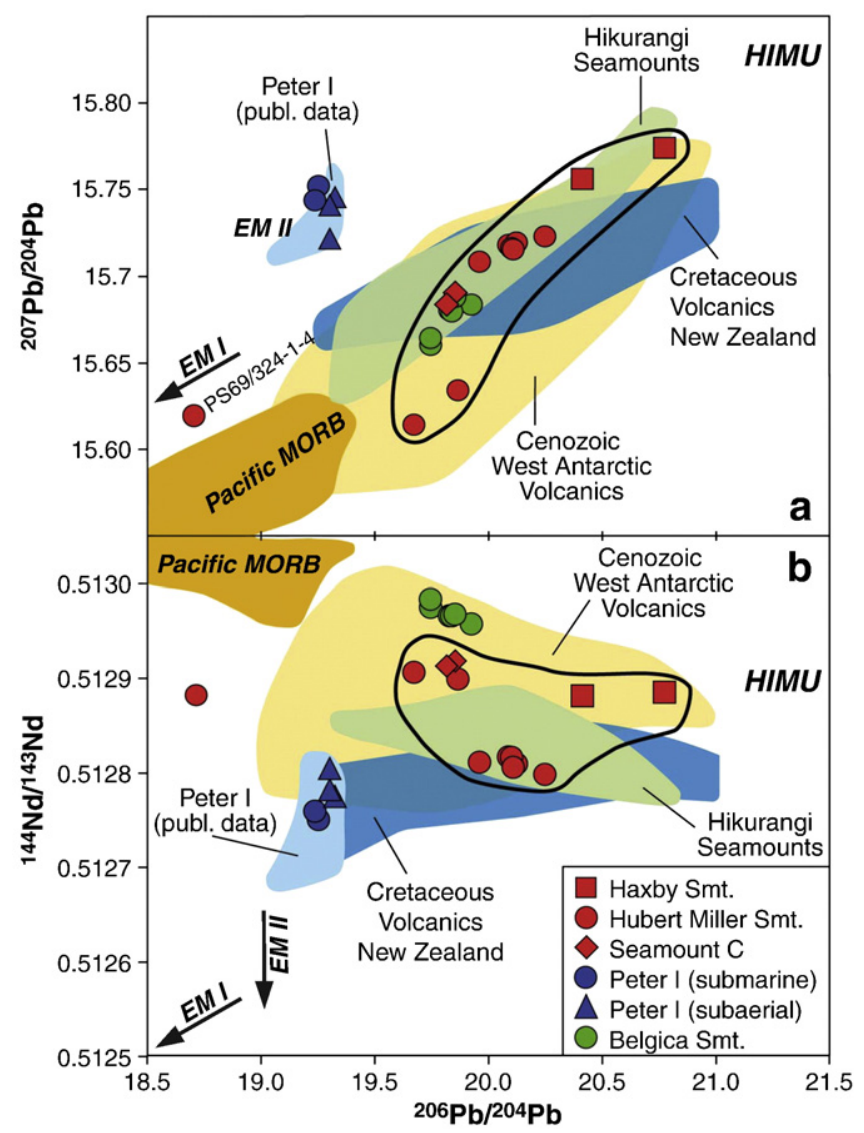

Fig. 11. (a) ${ }^{206} \mathrm{~Pb} /{ }^{204} \mathrm{~Pb}$ versus ${ }^{207} \mathrm{~Pb} /{ }^{204} \mathrm{~Pb}$, and (b) ${ }^{143} \mathrm{Nd} /{ }^{144} \mathrm{Nd}$ isotope correlation diagrams for MBS, Peter I Island, and Belgica Seamount samples. Symbols and data sources are as in Fig. 10.

than earlier published $\mathrm{K}-\mathrm{Ar}$ ages ( $327 \pm 88 \mathrm{ka}$ to $111 \pm 36 \mathrm{ka}$ [1 sigma errors], Prestvik and Duncan, 1991) obtained on subaerial samples, which suggests that the fresh pillow glasses belong to an earlier submarine phase of this volcano.

Together with published Upper Miocene $\mathrm{K}-\mathrm{Ar}$ ages for the Belgica Seamount (20-23 Ma, Hagedorn et al., 2007), the three seamount/ ocean island volcanic provinces of the Amundsen and Bellingshausen Sea appear to have formed at distinct age intervals of 64-57 Ma for the MBS, at 22 Ma for the De Gerlache Seamounts and at least

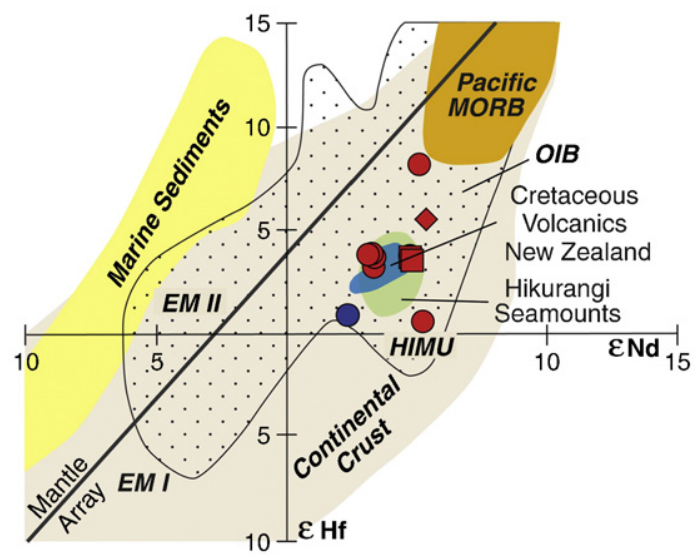

Fig. 12. $\varepsilon N d$ versus $\varepsilon H f$ isotope correlation diagram for MBS and Peter I Island samples. Figure modified after Geldmacher et al. (2003), symbols and data sources for Hikurangi Seamounts and Pacific MORB are as in Fig. 10. The New Zealand Cretaceous field includes Nd values by Tappenden (2003) and Hf values analyzed by Timm et al. (2010) for the Mandamus Complex, as well as data from McCoy-West et al. (2010) for Lookout Volcanics. since $\sim 2$ Ma at Peter I Island. The three seamount/ocean island groups are spatially arranged in a highly elongated triangle with the MBS lying at its western tip and the De Gerlache Seamounts and Peter I Island forming the eastern limit (Fig. 1). The age distribution neither shows a correlation with spatial distribution nor a correlation with the age of the underlying ocean crust (e.g., Eagles et al., 2004a). A relationship between ages and plate motion cannot be observed, because neither the relative motion between the Bellingshausen Plate and the Antarctic Plate nor the absolute plate motion of the Antarctic Plate was significant for this time period (Eagles et al., 2004a,b; Wobbe et al., 2012; Doubrovine et al., 2012).

Therefore, the irregular spatial distribution of seamount ages in the Amundsen Sea and Bellingshausen Sea indicates that this magmatism occurred at distinct time intervals in spatially confined areas. This observation excludes an origin through a single stationary hotspot sensu Morgan (1971). Instead this regional age pattern of intraplate volcanism favors the presence of three melting anomalies independent in space and time. Before we explore possibilities of non-plume related intraplate volcanism, we will first briefly reiterate geochemical constraints on the origin of the magma sources.

\subsection{Geochemical constraints on the origin of seamount magmatism}

Lavas of all three seamount provinces (MBS, De Gerlache and Peter I Island) display a strong enrichment of the LREE relative to the HREE (Fig. $8 \mathrm{c}+\mathrm{d}$ ), clearly indicating partial melting in the presence of garnet. Likewise $(\mathrm{Sm} / \mathrm{Yb})_{N},(\mathrm{Gd} / \mathrm{Yb})_{\mathrm{N}}$ and $(\mathrm{Dy} / \mathrm{Yb})_{\mathrm{N}}$ are all $>1$ which, is consistent with residual garnet in the source (cf. Fig. 9b). Furthermore, the slight enrichment of $\mathrm{Zr}$ relative to $\mathrm{Hf}$ on the mantle-normalized plot (Fig. $8 \mathrm{a}+\mathrm{b}$ ) is also consistent with residual garnet (Hauri et al., 1994). Consequently, melt segregation in all three areas must have occurred in the garnet stability field $>60-80 \mathrm{~km}$ or $40-50 \mathrm{~km}$ if garnet pyroxenite was in the source (Hirschmann and Stolper, 1996). High $\mathrm{Zr} / \mathrm{Hf}$ (43-54, Fig. 9b), Nb/Ta (16-19) and low Zr/Sm (31-38) provide additional support for partial melting of eclogite/garnet pyroxenite (i.e. recycled ocean crust), rather than garnet peridotite, consistent with a HIMU component in the mantle source.

The isotopic signatures of MBS volcanic rocks are consistent with the presence of a HIMU-type mantle component in the source of these rocks (Figs. 10-12). The extremely radiogenic ${ }^{206} \mathrm{~Pb} /{ }^{204} \mathrm{~Pb}$ of the HIMUendmember requires a high ${ }^{238} \mathrm{U} /{ }^{204} \mathrm{~Pb}$ in the source; a component unlikely to develop in significant amounts within the convecting upper oceanic mantle without crustal recycling (see Stracke, 2012 for a recent review). HIMU is classically thought to reflect deep mantle recycling of oceanic crust by mantle plumes, ascending from deep in the mantle (Hofmann and White, 1982; White, 2010), however, from the lack of clear indications for the long-term existence of a classical mantle plume in the Amundsen Sea it is clear that alternative mechanisms are required to explain the occurrence of HIMU-type intraplate volcanism in this area, as has also been proposed for HIMU-type volcanic rocks in New Zealand (Hoernle et al., 2006).

Subaerial and submarine samples of Peter I Island exhibit small compositional differences with the submarine samples having higher $\mathrm{SiO}_{2}$ and $\mathrm{Al}_{2} \mathrm{O}_{3}$ and slightly lower $\mathrm{MgO}$, FeOt and $\mathrm{TiO}_{2}$ contents than the subaerial samples. The slight differences in $\mathrm{MgO}, \mathrm{FeOt}, \mathrm{Al}_{2} \mathrm{O}_{3}$ and $\mathrm{TiO}_{2}$ between submarine and subaerial lavas could be related through fractionation of olivine, pyroxene and possibly ilmenite from a subaerial melt composition, but this scenario cannot explain the higher incompatible element abundances in the subaerial lavas. Along with the slightly more alkaline character of the subaerial lavas in our sample set, the data indicates that the subaerial lavas could reflect slightly lower degrees of mantle melting, which would also explain their higher incompatible element abundances. Variations in the extent of partial melting are common during the life cycle of ocean island volcanoes with more alkaline compositions of lavas during the subaerial stage compared to less alkaline (tholeiitic) compositions during the 
submarine shield stage (e.g., Frey et al., 1990). Even during the submarine stage, short-term variations in the degree of partial melting have been observed at Loihi Seamount in the Hawaiian Islands (Garcia et al., 1993).

The $\mathrm{Pb}$ isotopic composition of lavas from Peter I Island carries a clear EM II source signal (Fig. 11a) that is commonly thought to reflect contributions from pelagic sediments or upper continental crust (e.g., Zindler and Hart, 1986; Willbold and Stracke, 2010). The mafic composition of Peter I Island lavas, negative $\mathrm{Pb}$ anomalies and high $\mathrm{Ce} / \mathrm{Pb}$ ( 25 in submarine samples, 34-40 in subaerial samples) argue against shallow AFC processes such as sediment assimilation or preferred leaching of sedimentary $\mathrm{Pb}$. This conclusion is similar to that of Hart et al. (1995), who explain the high ${ }^{207} \mathrm{~Pb} /{ }^{204} \mathrm{~Pb}$ signature of Peter I Island melts as evidence for the involvement of a mantle plume with EM II characteristics. We also note that the majority of global pelagic sediments have lower ${ }^{206} \mathrm{~Pb} /{ }^{204} \mathrm{~Pb}$ and ${ }^{207} \mathrm{~Pb} /{ }^{204} \mathrm{~Pb}$ ratios than observed in the Peter I Island lavas and thus involvement of modern pelagic sediment seems less likely. This is consistent with the Hf-Nd isotope ratios, which show that marine sediments did not influence the submarine sample of Peter I Island (Fig. 12). Ce/Pb lying within (or slightly above) the canonical array of $25 \pm 5$ for global OIB and MORB (after Hofmann et al., 1986) provides additional evidence for derivation from oceanic mantle rather than involvement of continental crust, which has $\mathrm{Ce} / \mathrm{Pb}$ of 3-5. The solitary location of Peter I Island suggests that magmatism is related to a localized upwelling of EMII-like mantle but it is unclear whether this is connected to a blob rising from a thermal boundary such as the SW Pacific superswell or melting of a continental raft that drifted into the oceanic upper mantle during the final Gondwana breakup.

In summary, Cenozoic intraplate volcanism in the Amundsen Sea and Bellingshausen Sea requires involvement of depleted MORB mantle in the source with significant contributions of enriched components of HIMU and EM affinity. Due to the lack of clear evidence for the existence of a mantle plume in this region, a model is needed to explain the evidence for enriched (plume like) components in the source of Amundsen Sea intraplate volcanism and a non-plume related process to accomplish adiabatic mantle melting in an intraplate environment.

\subsection{Origin of the HIMU component in non-hotspot related Southwest-Pacific and Antarctic volcanic provinces}

Alkalic volcanism with HIMU-like incompatible-element and isotopic signatures, similar to the samples from MBS, is reported from numerous locations throughout the SW Pacific and West Antarctica. These include the Chatham Rise, Hikurangi Seamounts, intraplate volcanic fields in New Zealand, sub-Antarctic islands and West Antarctica

Fig. 13. Schematic sketch placing the origin of the MBS in a regional geodynamic context. (a) During the final stage of subduction of the Pacific Plate beneath the Zealandia/ West Antarctic Gondwana margin, the Hikurangi Plateau approaches the subduction zone. (b) Forces acting upon the plate margin as, for example, the collision of the Hikurangi Plateau with Zealandia (e.g., Bradshaw, 1989; Davy et al., 2008) cause cessation of subduction and slab detachment. The impact of a plume head at that time was accompanied by large scale underplating of HIMU material beneath East Gondwana (e.g., Weaver et al., 1994; Hart et al., 1997) and the Hikurangi Plateau (possibly by deflection of the plume material by the subducting plate; Hoernle et al., 2010), triggering volcanism on West Antarctica and Zealandia and the formation of the Hikurangi Seamounts. (c) After subduction ended, extensional processes set in, causing the break-up of Zealandia from Marie Byrd Land at $\sim 90 \mathrm{Ma}$ and subsequent rifting, forming the oceanic crust of the Amundsen Sea (Eagles et al., 2004a). (d) Lateral temperature differences between warm mantle beneath the continental lithosphere and normal upper mantle drove continental-insulation flow (model modified after King and Anderson, 1995), allowing sub-continental mantle material to rise into the upper mantle beneath the adjacent oceanic lithosphere. At the Cretaceous/Tertiary boundary lithospheric extension at the southern margin of the Bellingshausen Plate (e.g., Wobbe et al., 2012) formed deep reaching faults that allowed rise of plume type melts and formation of the MBS from a magma source similar to that of the Hikurangi Seamounts and the West-Antarctic/Zealandia volcanoes. For further details and references see text. (e.g., Weaver and Pankhurst, 1991; Baker et al., 1994; Weaver et al., 1994; Rocholl et al., 1995; Hart et al., 1997; Panter et al., 2000; Tappenden, 2003; Panter et al., 2006; Nardini et al., 2009; Hoernle et al., 2010). In all these localities, volcanic centers are diffusely distributed and do not show any age progression relative to plate motion. Most commonly, models suggest localized extension/upwelling of asthenosphere that induces melting of metasomatized lithosphere in thin spots to produce the diffuse alkaline magmatism.

Finn et al. (2005) postulate a "diffuse alkaline magmatic province (DAMP)", which formed without any rifting or plume upwelling. They temporally extend the DAMP into the Cenozoic and explain this magmatism by detachment of subducted slabs from the base of Gondwana lithosphere in the late Cretaceous. The sinking of material into the mantle is thought to have introduced Rayleigh Taylor instabilities

\section{a) Early Cretaceous subduction at East Gondwana margin}

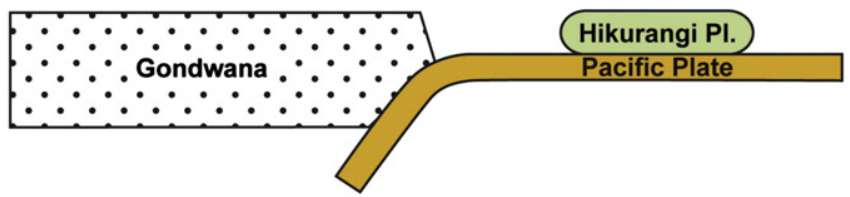

\section{b) Cessation of subduction at $\sim 100 \mathrm{Ma}$ and plume event}

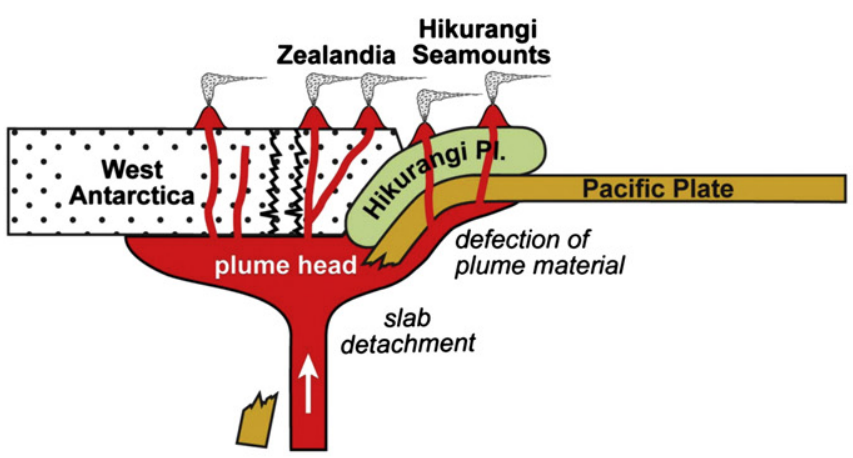

C) Break up at $\sim 90 \mathrm{Ma}$ and subsequent rifting

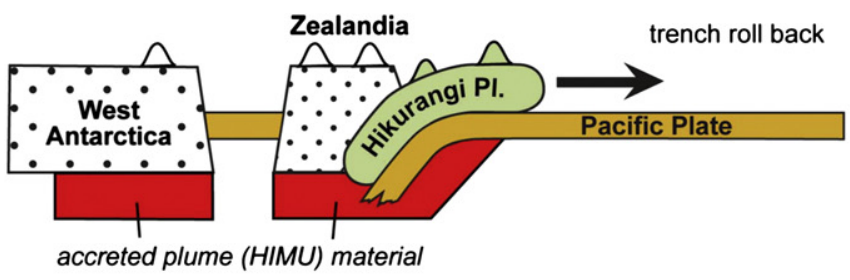

\section{d) Formation of the MBS at $\sim 65-55 \mathrm{Ma}$}

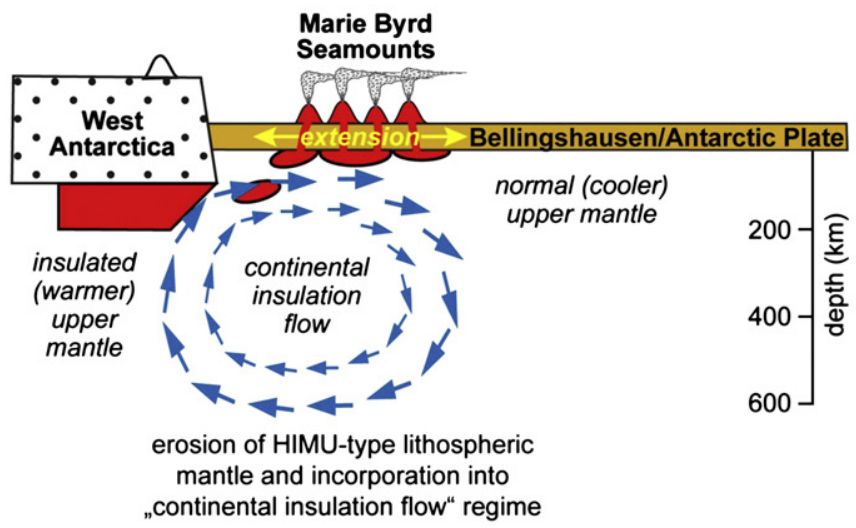


along the Gondwana margin and activated lateral and vertical flow of warm Pacific mantle. After Finn et al. (2005) the interaction of the warm mantle with metasomatized lithosphere generated the HIMU geochemical characteristics of the DAMP. A shortcoming of this model is, however, that Finn et al. (2005) had to focus their study on old, continental fragments of East Gondwana, and could not include oceanic occurrences like the MBS, the De Gerlache Seamounts or the Hikurangi Seamounts which are situated on top of Hikurangi Plateau off New Zealand. An important difference between the seamounts and the continental alkaline provinces is that the majority of seamount provinces formed on relatively young oceanic crust. While HIMU signatures can be found in old continental terranes, HIMU-type volcanism in the oceans either requires rise of HIMU material from depth or some sort of refertilization of the upper mantle, especially when required shortly after ocean crust formation. No doubt, small-scale heterogeneities exist in the upper mantle away from mantle plumes as is evident from small off-axis seamounts that often have more enriched element and isotopic signatures than associated MORB (e.g., Brandl et al., 2012 and references therein). It seems, however, unlikely that such smallscale heterogeneities are present shortly after formation of the ocean crust to an extent that can explain the c. $1000-8000 \mathrm{~km}^{3}$ of enriched melt required to form individual MBS (see Table 1 for volume estimates). In other words, even if Raleigh Taylor instabilities affected the Gondwana margin it seems unlikely that upwelling of regular Pacific upper mantle that underwent high degrees of melting shortly before can serve as the source of the HIMU-type compositions without refertilization.

Alternatively, the superplume beneath the SW-Pacific could have supplied a dense swarm of widely distributed and contemporaneously active secondary plumes causing diffuse alkaline volcanism (Suetsugu et al., 2009). Since it is in principle possible that secondary plumelets or blobs are continuously rising from the SW Pacific superswell (presumed to have stalled at the $660 \mathrm{~km}$ transition zone; Courtillot et al., 2003) they may also serve as the cause of volcanism forming the MBS and De Gerlache Seamounts. The age-distance relationship between MBS and the much farther north located Pacific Superswell is, however, unclear. Alternatively, Timm et al. (2010 and references therein) identify a low velocity anomaly extending from Chatham Rise off New Zealand to western Antarctica in at 600-1500 km depth and suggest that this could be the HIMU source polluting the upper mantle in this area since Cretaceous. Still it appears accidental that only the Marie Byrd Land margin was hit by a short-lived swarm of plumelets and no other oceanic region above this low velocity zone. Therefore we explore an alternative scenario for the oceanic seamount provinces off Marie Byrd Land based on reactivation of (HIMU) material, added to the base of continental lithosphere by plume activity during the pre-rifting stage of Marie Byrd Land/Zealandia.

On a regional scale, the MBS and Belgica Seamount data overlap with the data field of the Hikurangi Seamounts (Hoernle et al., 2010) in most isotope correlation diagrams (Figs. 10-12). A similar HIMU signature of Cretaceous rocks is also found at the Mandamus complex, the Lookout Volcanics in southern New Zealand, and the Chatham Islands (Weaver and Pankhurst, 1991; Tappenden, 2003; Panter et al., 2006; McCoy-West et al., 2010). During the Cretaceous these localities were assembled adjacent to Marie Byrd Land. It has been proposed that a HIMU-type plume or plume head may have caused breakup of the Gondwana margin in this region (e.g., Weaver et al., 1994; Hart et al., 1997; Storey et al., 1999; Hoernle et al., 2010). This plume event may have also influenced the source characteristics of the Hikurangi Seamounts (Hoernle et al., 2010) and may have been accompanied by large scale underplating of the Zealandia continental lithosphere by HIMU material (e.g. Weaver et al., 1994; Hart et al., 1997; Panter et al., 2000) (Fig. 13). During the mid Cretaceous the plume head expanded and thus forced rifting and the breakup of Gondwana as it impacted at the base of the continental lithosphere (Weaver et al., 1994). We note, however, that in contrast to other continental breakup related mantle plumes such as the Tristan-Gough in the
South-Atlantic (and related Paraná and Entendeka continental flood basalts), a flood basalt event is absent on Zealandia and West Antarctica, possibly reflecting the convergent margin setting and associated thick continental lithosphere along the Gondwana margin. Together with the observation that the Cretaceous HIMU volcanism occurred only locally and was of relatively low volume, it seems likely that unmelted HIMU-mantle got attached at the base the Gondwana lithosphere, which underwent extension and rifting during that period. The proposed large-scale underplating of HIMU material beneath East Gondwana is consistent with the HIMU signature of many Cenozoic continental volcanics from West Antarctica (e.g., Hobbs Coast, Marie Byrd Land Volcanic Province, and WARS; cf. Figs. 10 and 11). Accordingly, many authors relate the Cenozoic HIMU similarities in West Antarctica to the reactivation of HIMU material, added to the base of the continental lithosphere during the earliest pre-rifting stage of the Marie Byrd Land through plume activity (e.g., Weaver et al., 1994; Rocholl et al., 1995; Hart et al., 1997; Panter et al., 2000). Alternatively Nardini et al. (2009 and references therein) call upon a late Cretaceous metasomatic event that caused variable elevation of $\mathrm{U} / \mathrm{Pb}$ ratios in the sub-lithospheric mantle to an extend that explains the high ${ }^{206} \mathrm{~Pb} /{ }^{204} \mathrm{~Pb}$ of $<20$ Ma WARS volcanics and generation of their HIMU isotopic source signatures through radiogenic ingrowth over extremely short time scales. The regional context, however, requires the presence of a HIMU component that is already present in the Cretaceous, so that the metasomatic model of Nardini et al. (2009) for the formation of HIMU appears less likely.

Notably, the field for continental volcanic rocks of West Antarctica overlaps the data of the oceanic seamount provinces (Hikurangi Seamounts, MBS, De Gerlache) (Figs. 10 and 11), which have been formed close to the East Gondwana and West Antarctic margin, respectively. The samples also fall within the range of Cretaceous volcanic rocks of southern New Zealand, suggesting that all the above-mentioned volcanic suites originate from a similar HIMU source. This material may therefore also represent reactivation of fossil Cretaceous plume material that was originally attached to the base of the continental lithosphere during Marie Byrd Land/Zealandia break up. In contrast to the above mentioned onshore occurrences of Cenozoic HIMU volcanism, an additional transport mechanism and mode of reactivation is required to explain the marine equivalents of HIMU volcanism, because this material needs first of all be transferred into the oceanic mantle beneath the newly formed ocean basins of the Amundsen/Bellingshausen Sea followed by decompression melting (see Section 7.4 for details).

Admittedly, the arguments for an initial upwelling of plume-like material and storage at the base of the Gondwana lithosphere are solely based on geochemistry, which points to a HIMU like mantle. Such a source is unlikely to develop in situ in a mantle region affected by long-term subduction zone volcanism and small scale convection cells operating within the mantle wedge both leading to continuous depletion and replenishment of the arc mantle. On the other hand, upwelling of refertilized sub-continental lithospheric mantle (SCLM), isolated from mantle circulation for several billion years, can lead to the formation of EM type melts (e.g., Rudnick, 1995; Griffin et al., 2009; Hoernle et al., 2011; Soager et al., 2013). Ancient SCLM, however, features low ${ }^{206} \mathrm{~Pb} /{ }^{204} \mathrm{~Pb}$ and ${ }^{143} \mathrm{Nd} /{ }^{144} \mathrm{Nd}$ along with high ${ }^{207} \mathrm{~Pb} /{ }^{204} \mathrm{~Pb}$ and ${ }^{87} \mathrm{Sr} /{ }^{86} \mathrm{Sr}$ ratios, reflecting an ancient source that evolved with low $\mathrm{U} / \mathrm{Pb}, \mathrm{Sm} / \mathrm{Nd}$ but high $\mathrm{Rb} / \mathrm{Sr}$ (see Tang et al., 2013 for a recent review). Mantle regions that underwent such a fractionation and/or metasomatic event early in the earth's history are commonly thought to be involved in the formation of the early continental crust, having resided thereafter in the roots of stable Achaean cratons. In conclusion, SCLM seems to be a very unlikely candidate as source of the Cretaceous HIMU-type intraplate volcanism due the conflicting isotopic composition of SCLM (EM-like) and the long-term subduction zone setting of this area. Therefore, our preferred model for the origin of the HIMU component in the MBS and De Gerlache lavas is reactivation of fossil Cretaceous plume material, which was attached and stored at the base of the West Antarctic continental lithosphere during East Gondwana breakup. 


\subsection{Model for the formation of the Marie Byrd Seamounts}

In the case of the West Antarctic volcanoes, underplated HIMU material may have been reactivated and caused to upwell during the WARS extension (e.g., Hart et al., 1997). For the formation of the c. 99 to $67 \mathrm{Ma}$ Hikurangi Seamounts, Hoernle et al. (2010) propose the rise of HIMU-type material directly beneath the Hikurangi Plateau - a 118 Ma oceanic LIP (Hoernle et al., 2010) that formed in connection with the Manihiki (Timm et al., 2011) and possibly the Ontong Java Plateaus (Taylor, 2006), through deflection of rising plume material beneath Zealandia by the subducting plate towards the Hikurangi Plateau, which was about to collide with the Zealandia margin at that time (Fig. 13a + b). For the MBS and De Gerlache Seamounts, however, a mechanism is required that enables lateral transport of the earlier emplaced HIMU material under Marie Byrd Land beneath the newly formed bordering oceanic lithosphere.

When the new oceanic crust of the Amundsen Sea formed, Zealandia (including the Hikurangi Plateau) rifted away from Marie Byrd Land in a northward direction (Fig. 13c), whereas the West Antarctic continental margin remained more or less fixed and developed as a relatively stable passive margin thereafter (e.g., Eagles et al., 2004a; Wobbe et al., 2012). Mutter et al. (1988) proposed a transition zone directly at the edge of thicker to thinner lithosphere where small convective flow is focused. In case of the MBS and De Gerlache Seamounts, the transition zone lies at the edge of the Antarctic continental lithosphere and the beginning of the adjacent oceanic crust. Several mechanisms such as edge-driven convection (EDC), small-scale convection (SSC) or shear-driven upwelling (SDU) have been suggested to explain edge-driven buoyant flow between young, thin and old, thicker lithosphere (e.g., King and Anderson, 1995, 1998; King and Ritsema, 2000; Huang et al., 2003; Dumoulin et al., 2008; Conrad and Behn, 2010 and references therein). For example, (super-) continents may effectively insulate the upper mantle, leading to a buildup of heat (Anderson, 1994; Lowman and Jarvis, 1995, 1996; Gurnis et al., 1998). These lateral temperature differences between the warm mantle beneath the continental lithosphere and normal upper mantle can drive an upper mantle convective flow pattern that leads to upwelling beneath the continent-ocean transition zone (Fig. 13d), the so-called "continental-insulation flow" (e.g., King and Anderson, 1995, 1998). From numerical modeling, King and Anderson (1998) suggest that lateral variations in temperature of at least $30^{\circ} \mathrm{C}$ are required for continental insulation flow to significantly modify or even shut off the normal, downwelling EDC flow. Higher temperature anomalies $\left(150-200{ }^{\circ} \mathrm{C}\right.$ ) would drive major upper mantle convection cells. In case of the Cretaceous East Gondwana lithosphere, the impact of the hot plume head may have caused additional heating of the mantle beneath the continental lithosphere and therefore reinforced the lateral variations in mantle temperature and consequently mantle convection. Notably, the pattern of flow resulting from continental insulation is opposite to that of normal EDC flow (King and Anderson, 1995, 1998). At the initial stages of rifting of a continent, upwelling should occur as warm mantle from beneath the continent that occupies the space created by spreading between the continental masses. At the Late Cretaceous Marie Byrd Land margin, this process would transfer mantle material directly from beneath the continent into the upper mantle under the adjacent oceanic lithosphere on which the MBS started to form at that time (Fig. 13d). Therefore we consider continental insulation flow as the most plausible mechanism to bring the HIMU plume-like material previously attached beneath Marie Byrd Land upwards beneath the adjacent oceanic lithosphere of the Bellingshausen/Antarctic Plate.

As the HIMU material was transported upwards beneath the newly formed oceanic lithosphere from beneath the thick Antarctica continental crust, the material will melt by decompression. The volcanism forming the De Gerlache Seamounts at 22 Ma and the Pleistocene activity of Peter I Island, on the other hand, was most likely related to the De Gerlache Gravity Anomaly (Figs. 1 and 2), which represents a zone of lithospheric weakness resulting from a presumed WARS activity in this region (Müller et al., 2007), where pre-existing $\mathrm{N}-\mathrm{S}$ striking faults allowed rise (and decompression melting) of HIMU-type material brought up beneath the oceanic lithosphere by mantle convection. The formation of the MBS may therefore have been triggered by a complex sequence of plate reorganization events that affected the West Antarctic margin and the Bellingshausen Plate in Late Cretaceous and Early Cenozoic (e.g., Eagles et al., 2004a; Wobbe et al., 2012). Shortly before the Bellingshausen Plate became incorporated into the Antarctic Plate at 61 Ma (Eagles et al., 2004a,b; Wobbe et al., 2012), a change in rotation of the Bellingshausen Plate from counterclockwise to clockwise was accompanied by lithospheric extension on its southern margin between 74 and $62 \mathrm{Ma}$ (Wobbe et al., 2012). Contemporaneously the MBS started to form in that area (Fig. 2) (Fig. 13d), suggesting that lithospheric extension lead to upwelling of sub-lithospherically attached HIMU material and deep reaching faults that allowed rise of the HIMU-type melts and formation of large volcanic islands (Fig. 13d).

\section{Conclusions}

Our new morphological, geochronological, and geochemical data for the MBS combined with additional data for the De Gerlache and Peter I Island volcanic complexes (complementing previously published data) permit for the first time a comprehensive reconstruction of the origin and evolution of Cenozoic intraplate volcanism in the Amundsen Sea. The most important results are:

(1) Intraplate volcanism occurred during the entire Cenozoic at distinct time intervals in spatially confined areas in the Amundsen Sea, excluding an origin of this volcanism by a single stationary hotspot.

(2) The MBS and De Gerlache Seamount lavas show OIB signatures and posses a distinct HIMU component in their magma source similar to Late Cretaceous-Cenozoic volcanics of the Hikurangi Seamounts off New Zealand, intraplate volcanic fields in New Zealand, sub-Antarctic islands and the WARS, suggesting a common mantle source for these volcanic provinces.

(3) Peter I Island displays a strong EM affinity probably caused by shallow mantle recycling of a continental fragment.

Consequently, the formation of the MBS and De Gerlache Seamounts intraplate volcanism requires an alternative, non-hotspot scenario, which takes distinct melting anomalies independent in space and time and a non-hotspot related HIMU source into account.

Placing the morphological, geochronological, and geochemical data in a regional plate tectonic context, we conclude that the most plausible explanation for the HIMU-type intraplate volcanism in the Amundsen Sea is reactivation of HIMU-material, added to the base of the Antarctic lithosphere by a Late Cretaceous plume event. Major tectonic events, namely the separation of Zealandia from Antarctica during the final stage of the Gondwana break-up and subsequent formation of ocean crust give way for transport of the sub-lithospheric HIMU material beneath the Amundsen Sea oceanic crust by continental insulation flow. Extension caused by plate tectonic reorganization (MBS) and/or lithospheric weakening underneath the De Gerlache Gravity Anomaly (De Gerlache, Peter I Island) allow rise and adiabatic melting of the HIMU material resulting in the formation of these volcanic edifices. Reactivation of the MBS magmatism resulting in Pliocene low volume volcanism and the Pleistocene formation of Peter I Island documents ongoing magmatism in the Amundsen Sea.

The new model for the Amundsen Sea volcanism presented here adds to case examples for non-hotspot intraplate volcanism and provides additional evidence that HIMU-type intraplate volcanism is not necessarily a direct consequence of an actively upwelling, stationary mantle plume or hotspot. 
Supplementary data to this article can be found online at http:// dx.doi.org/10.1016/j.gr.2013.06.013.

\section{Acknowledgments}

We are grateful to Captain Pahl, the crew, and shipboard scientific party for their excellent support during RV Polarstern cruise ANT-XXIII/ 4. R. Gersonde (AWI) kindly provided the dredge samples from Belgica Seamount. D. Rau, S. Hauff, J. Sticklus (GEOMAR) and H. Anders (Uni-Bremen) are thanked for technical assistance during lab work and S. Gauger for help with processing of the bathymetric data. Discussions with Maxim Portnyagin, Jan Grobys, Graeme Eagles, and Christian Timm significantly helped to develop this paper. Furthermore, we are grateful for the constructive reviews of John Gamble and Tsuyoshi Komiya that helped to improve an earlier version of the manuscript. We thank Inna Yu Safonova for editorial handling and useful comments that helped to emphasize the importance of seamount formation. The German Research Foundation (DFG; Grants H01833/15-1 to -3 to $\mathrm{KH}$ and $\mathrm{FH}$ ) funded this research.

\section{References}

Anderson, D.L., 1994. Superplumes or supercontinents? Geology 22, 39-42. http:// dx.doi.org/10.1130/0091-7613(1994)022<0039:SOS >2.3.CO;2.

Anderson, D.L., 2000. The thermal state of the upper mantle; no role for mantle plumes. Geophysical Research Letters 27 (22), 3623-3626. http://dx.doi.org/10.1029/ 2000GL011533.

Baker, I.A. Gamble, J.A., Graham, IJ. 1994. The age, geology, and geochemistry of the Tapuaenuku Igneous Complex, Marlborough, New Zealand. New Zealand Journal of Geology and Geophysics 37, 249-268. http://dx.doi.org/10.1080/00288306.1994.9514620.

Baksi, A.K., 2007. A quantitative tool for detecting alteration in undisturbed rocks and minerals - I: water, chemical weathering, and atmospheric argon. Special Paper of the Geological Society of America 430 (1197), 285-303. http://dx.doi.org/ $10.1130 / 2007.2430(16)$

Batiza, R., Niu, Y., Zayac, W.C., 1990. Chemistry of seamounts near the East Pacific Rise: implications for the geometry of subaxial mantle flow. Geology 18, 1122-1125 (doi:1122-112510.1130/0091-7613(1990)018 < 1122:COSNTE > 2.3.CO;2).

Boger, S.D., 2011. Antarctica - before and after Gondwana. Gondwana Research 19 (2), 335-371. http://dx.doi.org/10.1016/j.gr.2010.09.003.

Bradshaw, J.D., 1989. Cretaceous geotectonic patterns in the New Zealand region. Tectonics 8, 803-820. http://dx.doi.org/10.1029/TC008i004p00803.

Brandl, P.A., Beier, C., Regelous, M., Abouchami, W., Haase, K.M., Garbe-Schönberg, D. Galer, S.J.G., 2012. Volcanism on the flanks of the East Pacific Rise: quantitative constraints on mantle heterogeneity and melting processes. Chemical Geology 298-299, 41-56. http://dx.doi.org/10.1016/j.chemgeo.2011.12.015.

Broch, O.A. 1927. Gesteine von der Peter I--Insel, West Antarktis. Avhandlinger/Det Norske Videnskaps-Akademi, I, Matematisk-Naturvidenskapelig Oslo KL 9, 1-41.

Buchs, D.M., Arculus, R.J., Baumgartner, P.O., Ulianov, A., 2011. Oceanic intraplate volcanoes exposed: example from seamounts accreted in Panama. Geology 39, 335-338. http://dx.doi.org/10.1130/G31703.1.

Conrad, C.P., Behn, M.D., 2010. Constraints on lithosphere net rotation and asthenospheric viscosity from global mantle flow models and seismic anisotropy. Geochemistry, Geophysics, Geosystems 11, Q05W05. http://dx.doi.org/10.1029/2009GC002970.

Courtillot, V., Davaille, A., Besse, J., Stock, J., 2003. Three distinct types of hotspots in the Earth's mantle. Earth and Planetary Science Letters 205, 295-308. http://dx.doi.org/ 10.1016/S0012-821X(02)01048-8.

Davy, B.W., Hoernle, K., Werner, R., 2008. Hikurangi Plateau: crustal structure, rifted formation, and Gondwana subduction history. Geochemistry, Geophysics, Geosystems 9, Q07004. http://dx.doi.org/10.1029/2007GC001855.

Doubrovine, P.V., Steinberger, B., Torsvik, T.H., 2012. Absolute plate motions in a reference frame defined by moving hot spots in the Pacific, Atlantic, and Indian oceans. Journal of Geophysical Research 117, B09101. http://dx.doi.org/10.1029/2011JB009072.

Dumoulin, C. Choblet, G., Doin, M.P. 2008. Convective interactions between oceanic lithosphere and asthenosphere: influence of a transform fault. Earth and Planetary Science Letters 274, 301-309. http://dx.doi.org/10.1016/j.epsl.2008.07.017.

Eagles, G., Gohl, K., Larter, R., 2004a. High-resolution animated tectonic reconstruction of the South Pacific and West Antarctic Margin. Geochemistry, Geophysics, Geosystems 5, Q07002. http://dx.doi.org/10.1029/2003GC000657.

Eagles, G., Gohl, K., Larter, R., 2004b. Life of the Bellingshausen Plate. Geophysical Research Letters 31, L07603. http://dx.doi.org/10.1029/2003GL019127.

Eagles, G., Larter, R., Gohl, K., Vaughan, A.P.M., 2009. West Antarctic Rift System in the Antarctic Peninsula. Geophysical Research Letters 36, L21305. http://dx.doi.org/ 10.1029/2009GL040721.

Feldberg, M.J., 1997. A Geophysical Study of Seamount E, Bellingshausen Sea, Antarctica. Diploma Degree of Bachelor of Arts Wesleyan University, USA.

Finn, C.A., Müller, R.D., Panter, K.S., 2005. A Cenozoic diffuse alkaline magmatic province in the SW Pacific without rift or plume origin. Geochemistry, Geophysics, Geosystems 6, Q02005. http://dx.doi.org/10.1029/2004GC000723.
Fisher, A.T., Davis, E.E., Hutnak, M., Spiess, V., Zühlsdorff, L., Cherkaoui, A., Christiansen, L., Edwards, K., Macdonald, R., Villinger, H., Mottl, M.J., Wheat, C.G., Becker, K., 2003. Hydrothermal recharge and discharge across $50 \mathrm{~km}$ guided by seamounts on a young ridge flank. Nature 421, 618-621. http://dx.doi.org/10.1038/nature01352.

Foulger, G.R., Natland, J.H., 2003. Is "hotspot" volcanism a consequence of plate tectonics? Science 300, 921-922. http://dx.doi.org/10.1126/science.1083376.

Frey, F.A., Wise, W.S., Garcia, M.O., West, H., Kwon, S.-T., Kennedy, A., 1990. Evolution of Mauna Kea Volcano, Hawaii: petrologic and geochemical constraints on postshield volcanism. Journal of Geophysical Research 95 (B2), 1271-1300. http://dx.doi.org/ 10.1029/JB095iB02p01271.

Garcia, M.O., Jorgenson, B.A., Mahoney, J.J., Ito, E., Irving, A.J., 1993. An evaluation of temporal geochemical evolution of Loihi Summit Lavas: results from Alvin submersible dives. Journal of Geophysical Research 98 (B1), 537-550. http://dx.doi.org/ 10.1029/92JB01707.

Geldmacher, J., Hanan, B.B., Blichert-Toft, J., Harpp, K., Hoernle, K., Hauff, F., Werner, R., und Kerr, A., 2003. Hf isotopic variations in volcanic rocks from the Caribbean Large Igneous Province and Galápagos hotspot tracks. Geochemistry, Geophysics, Geosystems 422 (7). http://dx.doi.org/10.1029/2002GC000477.

Geldmacher, J., Hoernle, K., van den Bogaard, P., Duggen, S., Werner, R., 2005. New ${ }^{40} \mathrm{Ar} /{ }^{39} \mathrm{Ar}$ age and geochemical data from seamounts in the Canary and Madeira volcanic provinces: support for the mantle plume hypothesis. Earth and Planetary Science Letters 237, 85-101. http://dx.doi.org/10.1016/j.epsl.2005.04.037.

Geldmacher, J., Hoernle, K., van den Bogaard, P., Hauff, F., Klügel, A., 2008. Age and geochemistry of the Central American forearc basement (DSDP Leg 67 and 84): insights into Mesozoic arc volcanism and seamount accretion on the fringe of the Caribbean LIP. Journal of Petrology 49, 1781-1815. http://dx.doi.org/10.1093/petrology/egn046.

Gohl, K., 2007. The expedition ANTARKTIS-XXIII/4 of the research vessel Polarstern in 2006. Berichte zur Polar- und Meeresforschung (Reports on Polar and Marine Research), no. 557. Alfred Wegener Institute for Polar and Marine Research, Bremerhaven (166 pp. http://epic.awi.de/26756/).

Gohl, K., Nitsche, F.O., Miller, H., 1997a. Seismic and gravity data reveal Tertiary interplate subduction in the Bellingshausen Sea, Southeast Pacific. Geology 25, 371-374. http://dx.doi.org/10.1130/0091-7613(1997)025<0371:SAGDRT>2.3.CO;2.

Gohl, K., Nitsche, F., Vanneste, K., Miller, H., Fechner, N., Oszko, L., Hübscher, C., Weigelt, E., Lambrecht, A., 1997b. Tectonic and sedimentary architecture of the Bellingshausen and Amundsen Sea Basins, SE Pacific, by seismic profiling. In: Ricci, C.A. (Ed.), The Antarctic Region: Geological Evolution and Processes. Terra Antartica Publication, Siena, pp. 719-723.

Gohl, K., Denk, A., Wobbe, F., Eagles, G., 2013. Deciphering tectonic phases of the Amundsen Sea Embayment shelf, West Antarctica, from a magnetic anomaly grid. Tectonophysics 585, 113-123. http://dx.doi.org/10.1016/j.tecto.2012.06.036.

Griffin, W.L., O'Reilly, S.Y, Afonso, J.C., Begg G.C. 2009. The composition and evolution of lithospheric mantle: a re-evaluation and its tectonic implications. Journal of Petrology 50, 1185-1204. http://dx.doi.org/10.1093/petrology/egn033.

Gurnis, M., Mueller, R.D., Moresi, L., 1998. Dynamics of Cretaceous vertical motion of Australia and the Australian-Antarctic discordance. Science 279, 1499-1504. http://dx.doi.org/10.1126/science.279.5356.1499.

Hagedorn, B., Gersonde, R., Gohl, K., Hubberten, H.-W., 2007. Petrology, geochemistry and $\mathrm{K}-\mathrm{Ar}$ age constraints of the eastern De Gerlache Seamount alkaline basalts (Bellingshausen Sea, Southeast Pacific). Polarforschung 76 (3), 87-94 (http:// epic.28876.d001)

Harris, R.N., Fisher, A.T., Chapman, D.S., 2004. Fluid flow through seamounts and implications for global mass fluxes. Geology 32, 725-728. http://dx.doi.org/10.1130/G20387.1.

Hart, S.R., Hauri, E.H., Oschmann, L.A., Whitehead, J.A., 1992. Mantle plumes and entrainment: isotopic evidence. Science 256, 517-520. http://dx.doi.org/10.1126/ science.256.5056.517.

Hart, S.R., Blusztajn, J., Craddock, C., 1995. Cenozoic volcanism in Antarctica: Jones Mountains and Peter I Island. Geochimica et Cosmochimica Acta 59, 3379-3388. http://dx.doi.org/10.1016/0016-7037(95)00212-I.

Hart, S.R., Blusztajn, J., LeMasurier, W.E., Rex, D.C., 1997. Hobbs Coast Cenozoic volcanism, implications for the West Antarctic Rift System. Chemical Geology 139, 223-248. http://dx.doi.org/10.1016/S0009-2541(97)00037-5.

Hauri, E.H., Whitehead, J.A., Hart, S.A., 1994. Fluid dynamic and geochemical aspects of entrainment in mantle plumes. Journal of Geophysical Research 99 (B12), 24275-24300. http://dx.doi.org/10.1029/94JB01257.

Hein, J.R., Conrad, T.A., Staudigel, H., 2010. Seamount mineral deposits: a source of rare metals for high-technology industries. Oceanography 23, 184-189. http:// dx.doi.org/10.5670/oceanog.2010.70

Heinemann, J., Stock, J., Clayton, R., Hafner, K., Cande, S., Raymond, C., 1999. Constraints on the proposed Marie Byrd Land-Bellingshausen Plate boundary from seismic reflection data. Journal of Geophysical Research 104 (B11), 25321-25330. http:// dx.doi.org/10.1029/1998JB900079.

Hirschmann, M.M., Stolper, E.M., 1996. A possible role for garnet pyroxenite in the origin of the "garnet signature" in MORB. Contributions to Mineralogy and Petrology 124, 185-208. http://dx.doi.org/10.1007/s004100050184.

Hoernle, K., van den Bogaard, P., Werner, R., Lissina, B., Hauff, F., Alvarado, G., GarbeSchönberg, D., 2002. Missing history (16-71 Ma) of the Galápagos hotspot: implications for the tectonic and biological evolution of the Americas. Geology 30, 795-798. http:// dx.doi.org/10.1130/0091-7613(2002)030<0795:mhmotg>2.0.co;2.

Hoernle, K., Hauff, F., Werner, R., Mortimer, N., 2004. New insights into the origin and evolution of the Hikurangi Oceanic Plateau (Southwest Pacific) from multi-beam mapping and sampling. Eos, Transactions of the American Geophysical Union 85 (41), 401-408. http://dx.doi.org/10.1029/2004E0410001.

Hoernle, K., White, J.D.L., van den Bogaard, P., Hauff, F., Coombs, D.S., Werner, R., Timm, C., Garbe-Schoenberg, D., Reay, A., Cooper, A.F., 2006. Cenozoic intraplate volcanism on 
New Zealand: upwelling induced by lithospheric removal. Earth and Planetary Science Letters 248, 350-367. http://dx.doi.org/10.1016/j.epsl.2006.06.001.

Hoernle, K., Hauff, F., van den Bogaard, P., Werner, R., Mortimer, N., Geldmacher, J., Garbe-Schoenberg, D., Davy, B., 2010. Age and geochemistry of volcanic rocks from the Hikurangi and Manihiki Oceanic Plateaus. Geochimica et Cosmochimica Acta 74 (24), 7196-7219. http://dx.doi.org/10.1016/j.gca.2010.09.030.

Hoernle, K., Hauff, F., Werner, R., van den Bogaard, P., Gibbons, A.D., Conrad, S., Müller, R.D., 2011. Origin of Indian Ocean Seamount Province by shallow recycling of continental lithosphere. Nature Geoscience 4, 883-887. http://dx.doi.org/10.1038/ngeo1331.

Hofmann, A.W., 1988. Chemical differentiation of the Earth: the relationship between mantle, continental and oceanic crust. Earth and Planetary Science Letters 90, 297-314. http://dx.doi.org/10.1016/0012-821X(88)90132-X.

Hofmann, A.W., 2003. Sampling mantle heterogeneity through oceanic basalts: isotopes and trace elements. In: Carlson, R.W. (Ed.), The Mantle and Core. Elsevier, Amsterdam, pp. 61-101. http://dx.doi.org/10.1016/B0-08-043751-6/02123-X.

Hofmann, A.W., White, W.M., 1982. Mantle plumes from ancient oceanic crust. Earth and Planetary Science Letters 57, 421-436. http://dx.doi.org/10.1016/0012-821X(82) 90161-3.

Hofmann, A.W., Jochum, K.-P., Seufert, M., White, W.M., 1986. Nb and Pb in oceanic basalts: new constraints on mantle evolution. Earth and Planetary Science Letters 79, 33-45. http://dx.doi.org/10.1016/0012-821X(86)90038-5.

Hole, M.J. LeMasurier, W.E., 1994. Tectonic controls on the geochemical composition of Cenozoic, mafic alkaline volcanic rocks from West Antarctica. Contributions to Mineralogy and Petrology 117, 187-202. http://dx.doi.org/10.1007/BF00286842.

Huang, J., Zhong, S., van Hunen, J., 2003. Controls on sub-lithospheric small-scale convection. Journal of Geophysical Research 108 (B8), 2405. http://dx.doi.org/10.1029/ 2003JB002456.

Hutnak, M., Fisher, A.T., Harris, R., Stein, C., Wang, K., Spinelli, G., Schindler, M., Villinger, H., Silver, E., 2008. Large heat and fluid fluxes driven through mid-plate outcrops on ocean crust. Nature Geoscience 1, 611-614. http://dx.doi.org/10.1038/ngeo264.

Irvine, T.N., Baragar, W.R.A., 1971. A guide to the chemical classification of the common volcanic rocks. Canadian Journal of Earth Sciences 8, 523-548. http://dx.doi.org/ 10.1139/e71-055.

King, S.D., Anderson, D.L., 1995. An alternative mechanism to flood basalt formation. Earth and Planetary Science Letters 136, 269-279. http://dx.doi.org/10.1016/ 0012-821X(95)00205-Q.

King, S.D., Anderson, D.L., 1998. Edge-driven convection. Earth and Planetary Science Letters 160, 289-296. http://dx.doi.org/10.1016/S0012-821X(98)00089-2.

King, S.D., Ritsema, J., 2000. African hotspot volcanism: small-scale convection in the upper mantle beneath cratons. Science 290, 1137-1140. http://dx.doi.org/10.1126/ science.290.5494.1137.

Klügel, A., Hansteen, T.H., van den Bogaard, P., Strauss, H., Hauff, F., 2011. Holocene fluid venting at an extinct Cretaceous seamount, Canary Archipelago. Geology 39, 855-858. http://dx.doi.org/10.1130/G32006.1

Koppers, A.A.P., Yamazaki, T., Geldmacher, J., Gee, J.S., Pressling, N., IODP Expedition 330 Scientific Party, 2012. Limited latitudinal mantle plume motion for the Louisville hotspot. Nature Geoscience 5, 911-917. http://dx.doi.org/10.1038/ngeo1638.

Larter, R.D., Cunningham, A.P., Barker, P.F., Gohl, K., Nitsche, F.O., 2002. Tectonic evolution of the Pacific margin of Antarctica - 1. Late Cretaceous tectonic reconstructions. Journal of Geophysical Research 107 (B12), 2345. http://dx.doi.org/10.1029/2000JB000052.

LeMasurier, W.E., Thomson, J.W., Baker, P., Kyle, P., Rowley, P., Smellie, J., Verwoerd, W. (Eds.), 1990. Volcanoes of the Antarctic Plate and Southern Oceans. Antarctic Research Series, 48. AGU, Washington, D.C., p. 487. http://dx.doi.org/10.1029/AR048.

Lowman, J.P., Jarvis, G.T., 1995. Mantle convection models of continental collision and breakup incorporating finite thickness plates. Physics of the Earth and Planetary Interiors 88, 53-68. http://dx.doi.org/10.1016/0031-9201(94)05076-A.

Lowman, J.P., Jarvis, G.T., 1996. Continental collisions in wide aspect ratio and high Rayleigh number two-dimensional mantle convection models. Journal of Geophysical Research 101 (B11), 25485-25497. http://dx.doi.org/10.1029/96JB02568.

McAdoo, D.C., Laxon, S., 1997. Antarctic tectonics: constraints from an ERS-1 satellite marine gravity field. Science 276, 556-560. http://dx.doi.org/10.1126/science.276.5312.556.

McCoy-West, A.J., Baker, J.A., Faure, K., Wysoczanski, R., 2010. Petrogenesis and origins of mid-Cretaceous continental intraplate volcanism in Marlborough, New Zealand: implications for the long-lived HIMU magmatic mega-province of the SW Pacific Journal of Petrology 51, 2003-2045. http://dx.doi.org/10.1093/petrology/egq046.

McDonough, W.F., Sun, S.-S., 1995. The composition of the earth. Chemical Geology 120, 223-253. http://dx.doi.org/10.1016/0009-2541(94)00140-4.

McMurtry, G.M., Fryer, G.J., Tappin, D.R., Wilkinson, I.P., Williams, M., Fietzke, J., GarbeSchönberg, D., Watts, P., 2004. Megatsunami deposits on Kohala Volcano, Hawaii, from flank collapse of Mauna Loa. Geology 32, 741-744. http://dx.doi.org/10.1130/G20642.1.

Miller, H., Grobe, H., 1996. The expedition ANTARKTIS-XI/3 of RV 'Polarstern' in 1994. Berichte zur Polarforschung, no. 188 (http://epic.10189.d001).

Montelli, R., Nolet, G., Dahlen, F.A., Masters, G., 2006. A catalogue of deep mantle plumes: new results from finite-frequency tomography. Geochemistry, Geophysics, Geosystems 7, Q11007. http://dx.doi.org/10.1029/2006GC001248.

Morgan, W.J., 1971. Convection plumes in the lower mantle. Nature 230, 42-43. http:// dx.doi.org/10.1038/230042a0.

Müller, R.D., Gaina, C., Tikku, A., Mihut, D., Cande, S.C., Stock, J.M., 2000. Mesozoic/Cenozoic tectonic events around Australia. Geophysical Monograph 121, 161-188. http://dx.doi.org/10.1029/GM121p0161.

Müller, R.D., Gohl, K., Cande, S.C., Goncharov, A., Golynsky, A.V., 2007. Eocene to Miocene geometry of the West Antarctic Rift System. Australian Journal of Earth Sciences 54, 1033-1045. http://dx.doi.org/10.1080/08120090701615691.

Mutter, J.C., Buck, W.R., Zehnder, C.M., 1988. Convective partial melting 1. A model for the formation of thick basaltic sequences during the initiation of spreading. Journal of Geophysical Research 93 (B2), 1031-1048. http://dx.doi.org/10.1029/J093iB02p01031.
Nardini, I., Armienti, P., Rocchi, S., Dallai, L., Harrison, D., 2009. Sr-Nd-Pb-He-O isotope and geochemical constraints on the genesis of Cenozoic magmas from the West Antarctic Rift. Journal of Petrology 50 (7), 1359-1375. http://dx.doi.org/10.1093/ petrology/egn082.

Natland, J.H., Winterer, E.L., 2005. Fissure control on volcanic action in the Pacific. In: Foulger, G.R., Natland, J.H., Presnall, D.C., Anderson, D.L. (Eds.), Plumes, Plates and Paradigms. Geological Society of America, Boulder CO, pp. 687-710. http:// dx.doi.org/10.1130/0-8137-2388-4.687.

Panter, K.S., Kyle, P.R., Smellie, J.L., 1997. Petrogenesis of a phonolite-trachyte succession at Mount Sidley, Marie Byrd Land, Antarctica. Journal of Petrology 38 (9), 1225-1253. http://dx.doi.org/10.1093/petroj/38.9.1225.

Panter, K.S., Hart, S.R., Kyle, P., Blusztanjn, J., Wilch, T., 2000. Geochemistry of Late Cenozoic basalts from the Crary Mountains: characterization of mantle sources in Marie Byrd Land, Antarctica. Chemical Geology 165, 215-241. http://dx.doi.org/ 10.1016/S0009-2541(99)00171-0.

Panter, K.S., Blusztanjn, J., Hart, S.R., Kyle, P.R., Esser, R., McIntash, W.C., 2006. The origin of HIMU in the SW Pacific: evidence from intraplate volcanism in southern New Zealand and Subantarctic islands. Journal of Petrology 47, 1673-1704. http://dx.doi.org/10.1093/petrology/egl024.

Portnyagin, M., Savelyev, D., Hoernle, K., Hauff, F., Garbe-Schönberg, D., 2008. MidCretaceous Hawaiian tholeiites preserved in Kamchatka. Geology 36, 903-906 http://dx.doi.org/10.1130/g25171a.1.

Prestvik, T., Duncan, R.A., 1991. The geology and age of Peter I Øy, Antarctica. Polar Research 9, 89-98. http://dx.doi.org/10.1111/j.1751-8369.1991.tb00404.x.

Prestvik, T., Barnes, C.G., Sundvoll, B., Duncan, R.A., 1990. Petrology of Peter I Øy (Peter I Island), West Antarctica. Journal of Volcanology and Geothermal Research 44, 315-338. http://dx.doi.org/10.1016/0377-0273(90)90025-B.

Rocchi, S., Armienti, P., D'Orazio, M., Tonarini, S., Wijbrans, J., Di Vincenzo, G., 2002a. Cenozoic magmatism in the western Ross Embayment: role of mantle plume versus plate dynamics in the development of the West Antarctic Rift System. Journal of Geophysical Research 107 (B9), 2195. http://dx.doi.org/10.1029/2001JB000515.

Rocchi, S., LeMasurier, W.E., Di Vincenzo, G., 2002b. Uplift and erosion history in Marie Byrd Land as a key to possible mid-Cenozoic plate motion between East and West Antarctica. Geological Society of America Abstracts with Programs 34 (6), 238.

Rocholl, A., Stein, M., Molzahn, M., Hart, S.R., Wörner, G., 1995. Geochemical evolution of rift magmas by progressive tapping of a stratified mantle source beneath the Ross Sea Rift, Northern Victoria Land, Antarctica. Earth and Planetary Science Letters 131, 207-224. http://dx.doi.org/10.1016/0012-821X(95)00024-7.

Rudnick, R.L., 1995. Making continental crust. Nature 378, 571-578. http://dx.doi.org/ 10.1038/378571a0.

Safonova, I.Y., 2009. Intraplate magmatism and oceanic plate stratigraphy of the PaleoAsian and Paleo-Pacific Oceans from 600 to 140 Ma. Ore Geology Reviews 35, 137-154. http://dx.doi.org/10.1016/j.oregeorev.2008.09.002.

Safonova, I.Y., Santosh, M., 2012. Accretionary complexes in the Asia-Pacific region: tracing archives of ocean plate stratigraphy and tracking mantle plumes. Gondwana Research 25, 126-158.

Salters, V.J.M., Stracke, A., 2004. Composition of the depleted mantle. Geochemistry, Geophysics, Geosystems 5, Q05B07. http://dx.doi.org/10.1029/2003GC000597.

Shank, T.M., 2010. Seamounts: deep-ocean laboratories of faunal connectivity, evolution, and endemism. Oceanography 23, 108-122. http://dx.doi.org/10.5670/ oceanog.2010.65

Smith, W.H.F., Sandwell, D.T., 1997. Global sea floor topography from satellite altimetry and ship depth soundings. Science 277, 1956-1962. http://dx.doi.org/10.1126/ science.277.5334.1956.

Soager, N., Holm, P.M., Llambias, E.J., 2013. Payenia volcanic province, southern Mendoza, Argentina: OIB mantle upwelling in a backarc environment. Chemical Geology 349-350, 36-53. http://dx.doi.org/10.1016/j.chemgeo.2013.04.007.

Stock, J.M., 1997. Geophysical secrets beneath Antarctic waters. Engineering Sciences 60 (3), 18-27.

Storey, B.C., Leat, P.T., Weaver, S.D., Pankhurst, R.J., Bradshaw, J.D., Kelley, S., 1999 Mantle plumes and Antarctica-New Zealand rifting; evidence from MidCretaceous mafic dykes. Journal of the Geological Society 156, 659-671. http:// dx.doi.org/10.1144/gsjgs.156.4.0659.

Stracke, A., 2012. Earth's heterogeneous mantle: a product of convection-driven interaction between crust and mantle. Chemical Geology 330-331, 274-299. http:// dx.doi.org/10.1016/j.chemgeo.2012.08.007.

Suetsugu, D., Isse, T., Tanaka, S., Obayashi, M., Shiobara, H., Sugioka, H., Kanazawa, T. Fukao, Y., Barruol, G., Reymond, D., 2009. South Pacific mantle plumes imaged by seismic observation on islands and seafloor. Geochemistry, Geophysics, Geosystems 10, Q11014. http://dx.doi.org/10.1029/2009GC002533.

Sun, S.S., McDonough, W.F., 1989. Chemical and isotopic systematics of oceanic basalts: implications for mantle composition and processes. In: Saunders, A.D., Norry, M.J. (Eds.), Magmatism in the Ocean Basins. Geological Society Special Publications, 42, pp. 313-345. http://dx.doi.org/10.1144/GSL.SP.1989.042.01.19.

Sutherland, R., Spasojevic, S., Gurnis, M., 2010. Mantle upwelling after Gondwana subduction death explains anomalous topography and subsidence history of eastern New Zealand and West Antarctic. Geology 38, 155-158. http://dx.doi.org/10.1130/G30613.1.

Tang, Y.-J., Zhang, H.-F., Ying, J.-F., Su, B.-X., 2013. Widespread refertilization of cratonic and circum-cratonic lithospheric mantle. Earth-Science Reviews 118, 45-68. http://dx.doi.org/10.1016/j.earscirev.2013.01.004.

Tappenden, V.E., 2003. Magmatic Response to the Evolving New Zealand Margin of Gondwana During the Mid-Late Cretaceous. (PhD thesis) University of Canterbury, Christchurch, New Zealand.

Tarduno, J.A., Duncan, R.A., Scholl, D.W., Cottrell, R.D., Steinberger, B., Thordason, T. Kerr, B.C., Neal, C.R., Frey, F.A., Torii, M., Carvallo, C., 2003. The Emperor Seamounts: 
southward motion of the Hawaiian hotspot plume in earth's mantle. Science 301 1064-1069. http://dx.doi.org/10.1126/science.1086442.

Taylor, B., 2006. The single largest oceanic plateau: Ontong Java-Manihiki-Hikurangi. Earth and Planetary Science Letters 241, 372-380. http://dx.doi.org/10.1016/ j.epsl.2005.11.049.

Timm, C., Hoernle, K., Werner, R., Hauff, F., van den Bogaard, P., White, J., Mortimer, N., Garbe-Schoenberg, D., 2010. Temporal and geochemical evolution of the Cenozoic intraplate volcanism of Zealandia. Earth-Science Reviews 98, 38-64. http:// dx.doi.org/10.1016/j.earscirev.2009.10.002.

Timm, C., Hoernle, K., Werner, R., Hauff, F., van den Bogaard, P., Michael, P., Coffin, M. Koppers, A., 2011. Age and geochemistry of the oceanic Manihiki Plateau, SW Pacific: new evidence for a plume origin. Earth and Planetary Science Letters 304 (1-2), 135-146. http://dx.doi.org/10.1016/j.epsl.2011.01.025.

Udintsev, G.B., Kurentsova, N.A., Teterin, D.E., Roshchina, I.A., 2007. Petrology of the Hubert Miller Seamount, Marie Byrd Seamounts Province, West Antarctic, Southern Ocean. Doklady Earth Sciences 415A (6), 895-900. http://dx.doi.org/10.1134/ S1028334X07060141

Uenzelmann-Neben, G., Gohl, K., 2012. Amundsen Sea sediment drifts: archives of modifications in oceanographic and climatic conditions. Marine Geology 299-302, 51-62. http://dx.doi.org/10.1016/j.margeo.2011.12.007.

Watts, A.B., Koppers, A.A.P., Robinson, D.P., 2010. Seamount subduction and earthquakes. Oceanography 23 (1), 166-173. http://dx.doi.org/10.5670/ oceanog.2010.68\#sthash.6fn0xSSg.dpuf.

Weaver, S.D., Pankhurst, R.J., 1991. A precise Rb-Sr age for the Mandamus Igneous Complex, North Canterbury, and regional tectonic implications. New Zealand Journal of Geology and Geophysics 34, 341-345. http://dx.doi.org/10.1080/ 00288306.1991.9514472.
Weaver, S.D., Storey, B.C., Pankhurst, R.J., Mukasa, S.B., DiVenere, V.J., Bradshaw, J.D., 1994. Antarctica-New Zealand rifting and Marie Byrd Land lithospheric magmatism linked to ridge subduction and mantle plume activity. Geology 22, 811-814. http://dx.doi.org/10.1130/0091-7613(1994)022<0811: ANZRAM $>2.3 . \mathrm{CO} ; 2$.

Wessel, P., Sandwell, D.T., Kim, S.-S., 2010. The global seamount census. Oceanography 23, 24-33. http://dx.doi.org/10.5670/oceanog.2010.60.

White, W.M., 2010. Oceanic island basalts and mantle plumes: the geochemical perspective. Annual Review of Earth and Planetary Sciences 38, 133-160. http:// dx.doi.org/10.1146/annurev-earth-040809-152450.

Willbold, M., Stracke, A., 2010. Formation of enriched mantle components by recycling of upper and lower continental crust. Chemical Geology 276, 188-197. http:// dx.doi.org/10.1016/j.chemgeo.2010.06.005.

Wilson, J.T., 1963. Evidence from islands on the spreading of the ocean floor. Nature 197, 536-538. http://dx.doi.org/10.1038/197536a0.

Winterer, E.L., Sandwell, D.T., 1987. Evidence from en-echelon cross-grain ridges for tensional cracks in the Pacific Plate. Nature 329, 534-537. http://dx.doi.org/ 10.1038/329534a0.

Wobbe, F., Gohl, K., Chambord, A., Sutherland, R., 2012. Structure and breakup history of the rifted margin of West Antarctica in relation to Cretaceous separation from Zealandia and Bellingshausen Plate motion. Geochemistry, Geophysics, Geosystems 13, Q04W12. http://dx.doi.org/10.1029/2011GC003742.

Workman, R.K., Hart, S.R., 2005. Major and trace element composition of the depleted MORB mantle (DMM). Earth and Planetary Science Letters 231, 53-72. http:// dx.doi.org/10.1016/j.epsl.2004.12.005.

Zindler, A., Hart, S.R., 1986. Chemical geodynamics. Annual Review of Earth and Planetary Sciences 14, 493-571. http://dx.doi.org/10.1146/annurev.ea.14.050186.002425. 